Review

\title{
Herbaceous Oil Crops, a Review on Mechanical Harvesting State of the Art
}

\author{
Luigi Pari *(D), Francesco Latterini ${ }^{(}$and Walter Stefanoni $\left.{ }^{(}\right)$ \\ Consiglio per la Ricerca in Agricoltura e l'analisi dell'Economia Agraria (CREA)—Centro di Ricerca Ingegneria e \\ Trasformazioni Agroalimentari, Via della Pascolare, 16, 00015 Monterotondo (RM), Italy; \\ francesco.latterini@crea.gov.it (F.L.); walter.stefanoni@crea.gov.it (W.S.) \\ * Correspondence: luigi.pari@crea.gov.it; Tel.: +39-0690675250
}

Received: 12 June 2020; Accepted: 22 July 2020; Published: 23 July 2020

check for updates

\begin{abstract}
The sustainable production of renewable energy is a key topic on the European community's agenda in the next decades. The use of residuals from agriculture could not be enough to meet the growing demand for energy, and the contribution of vegetable oil to biodiesel production may be important. Moreover, vegetable oil can surrogate petroleum products in many cases, as in cosmetics, biopolymers, or lubricants production. However, the cultivation of oil crops for the mere production of industrial oil would arise concerns on competition for land use between food and non-food crops. Additionally, the economic sustainability is not always guaranteed, since the mechanical harvesting, in some cases, is still far from acceptable. Therefore, it is difficult to plan the future strategy on bioproducts production from oil crops if the actual feasibility to harvest the seeds is still almost unknown. With the present review, the authors aim to provide a comprehensive overview on the state of the art of mechanical harvesting in seven herbaceous oil crops, namely: sunflower (Heliantus annuus L.), canola (Brassica napus L.), cardoon (Cynara cardunculus L.), camelina (Camelina sativa (L.) Crantz), safflower (Carthamus tinctorius L.), crambe (Crambe abyssinica R. E. Fr.), and castor bean (Ricinus communis L.). The review underlines that the mechanical harvesting of sunflower, canola and cardoon seeds is performed relying on specific devices that perform effectively with a minimum seed loss. Crambe and safflower seeds can be harvested through a combine harvester equipped with a header for cereals. On the other hand, camelina and castor crops still lack the reliable implementation on combine harvesters. Some attempts have been performed to harvest camelina and castor while using a cereal header and a maize header, respectively, but the actual effectiveness of both strategies is still unknown.
\end{abstract}

Keywords: harvesting; work productivity; supply chain; harvesting efficiency

\section{Introduction}

The European Directives on Renewable Energy (RED I and RED II) [1] aim to increase the share of renewable energy up to $32 \%$ of overall domestic energy production by 2030 . Agriculture plays a key role in such context [2]; indeed, this sector can contribute to bioenergy production both with the exploitation of agricultural residues [3-6] and with dedicated energy crops [7-10]. Concerning the latter strategy, biodiesel production from oil crops is crucial [11]. Oil crops are able to synthesize highly complex molecular structures that can be used to displace significant amount of petroleum oil derived compounds [12] and they can significantly contribute to reach the above mentioned European Directives about renewable energy [13]. Moreover, oil crops contribution to bioeconomy concept is not only limited to bioenergy production, while taking into account the suitability of vegetable oil to be used as feedstock for the production of several bioproducts, such as surfactants, plasticizers, emulsifiers, detergents, lubricants, adhesives, and cosmetics [12,14]. However, two main issues are 
related to sustainable cultivation of oil crops. The first one is linked to avoid the competition with food crops considering the global increasing demand for food [15]. Scientific community has been working hardly to address this issue for years, mainly evaluating the possibilities of cultivating such crops in polluted soils [16,17] or in marginal lands [18-20]. The second one regards the costs of production costs of biodiesel, which is $30 \%$ more costly than petroleum-based diesel [21]. In particular, $60-80 \%$ of the biodiesel production cost is linked to the raw materials [11]; hence, there is a strong need to reduce the supply chain costs.

A possible strategy to reach this goal is to improve the harvesting operations. Harvesting is the key stage of the supply chain that strongly affects both costs and biomass quality and it plays a key role in the three pillars of the sustainability [22-31]. In a developed country, it is practically impossible to set up a sustainable supply chain for a given crop without effective mechanical harvesting [32]. The labor costs would be too high to bear. The mechanical harvesting of a given crop can be performed either using a dedicated harvester or borrowing it from other crops and apply specific modifications, at different levels, in order to limit the loss and damage to kernels [32]. The availability of dedicated machines is not always guaranteed, since different challenges arise according to the phenology of the plant and the seeds. Oil crops suffer the lack of availability on the market of dedicated machines for the harvesting stage, and the present review aims to provide the reader with the state of the art of mechanical harvesting, focusing on large scale oilseed production of some herbaceous oil crops, relying on the references that are produced in the last two decades (reference period 2000-2020).

Seven herbaceous oil crops have been taken into account, namely: sunflower (Heliantus annuus L.), canola (Brassica napus L.), cardoon (Cynara cardunculus L.), camelina (Camelina sativa (L.) Crantz), safflower (Carthamus tinctorius L.), crambe (Crambe abyssinica R. E. Fr.), and castor bean (Ricinus communis L.). The common feature to all these species is that all of them are herbaceous oil crops whose oil is the main product.

After the present introduction section, materials and methods for the review are reported. Subsequently, each crop is treated in a dedicated paragraph, in which, as a first step, a general view about the species is given (i.e., main agricultural features, actual and possible uses of oil, possibility of exploitation of by-products), then the mechanical harvesting topic is reported in detail. Eventually, the discussions and conclusion section are reported.

\section{Materials and Methods}

The bibliographical search was performed through Boolean operators. The use of Boolean searching to carry out a systematic review allows to analyze all studies in a given research topic through the use of specific database [33], in particular Scopus repository, was used for the present work. A papers search within Scopus database was done looking for both the common name and binomial one for each crop along with the word "harvest*". Table 1 provides details of the research keys and of relative findings.

Table 1. Research keys and findings on Scopus database.

\begin{tabular}{|c|c|c|c|c|}
\hline Research Key & $\begin{array}{l}\text { Overall } \\
\text { Findings }\end{array}$ & $\begin{array}{l}2000-2020 \text { and } \\
\text { English Language } \\
\text { Findings }\end{array}$ & $\begin{array}{l}\text { 2000-2020 Papers } \\
\text { Actually Dealing with } \\
\text { Mechanical Harvesting }\end{array}$ & $\begin{array}{l}\text { Reference } \\
\text { n. }\end{array}$ \\
\hline TITLE-ABS-KEY (“sunflower” AND “harvest *”) & 1020 & 773 & \multirow[b]{2}{*}{7} & \multirow[b]{2}{*}{ [34-40] } \\
\hline $\begin{array}{l}\text { TITLE-ABS-KEY ("Heliantus annuus" AND } \\
\text { "harvest *”) }\end{array}$ & 427 & 323 & & \\
\hline TITLE-ABS-KEY (“canola” AND “harvest*”) & 633 & 380 & \multirow{4}{*}{16} & \multirow{4}{*}{ [41-56] } \\
\hline $\begin{array}{c}\text { TITLE-ABS-KEY (“Brassica napus” AND } \\
\text { "harvest*”) }\end{array}$ & 1244 & 1016 & & \\
\hline $\begin{array}{c}\text { TITLE-ABS-KEY ("oilseed rape" AND } \\
\text { "harvest*") }\end{array}$ & 553 & 269 & & \\
\hline TITLE-ABS-KEY ("rapeseed” AND “harvest *”) & 742 & 577 & & \\
\hline
\end{tabular}


Table 1. Cont.

\begin{tabular}{|c|c|c|c|c|}
\hline Research Key & $\begin{array}{l}\text { Overall } \\
\text { Findings }\end{array}$ & $\begin{array}{l}\text { 2000-2020 and } \\
\text { English Language } \\
\text { Findings }\end{array}$ & $\begin{array}{l}\text { 2000-2020 Papers } \\
\text { Actually Dealing with } \\
\text { Mechanical Harvesting }\end{array}$ & $\begin{array}{c}\text { Reference } \\
\text { n. }\end{array}$ \\
\hline \multirow{2}{*}{$\begin{array}{l}\text { TITLE-ABS-KEY (“cardoon” AND “harvest *") } \\
\text { TITLE-ABS-KEY (“Cynara cardunculus" AND } \\
\text { "harvest*”) }\end{array}$} & 59 & 58 & & \multirow[b]{2}{*}[32,57-62]{} \\
\hline & 143 & 142 & 7 & \\
\hline TITLE-ABS-KEY (“camelina" AND “harvest *”) & 67 & 66 & 4 & [63-66] \\
\hline $\begin{array}{l}\text { TITLE-ABS-KEY (“castor" AND “harvest *") } \\
\text { TITLE-ABS-KEY ("Ricinus communis" AND } \\
\text { "harvest *") }\end{array}$ & 156 & 112 & 2 & {$[67,68]$} \\
\hline \multirow{2}{*}{$\begin{array}{l}\text { TITLE-ABS-KEY ("safflower" AND “harvest *") } \\
\text { TITLE-ABS-KEY ("Carthamus tinctorius" AND } \\
\text { "harvest *") }\end{array}$} & 165 & 83 & \multirow[b]{2}{*}{1} & \multirow[b]{2}{*}{ [69] } \\
\hline & 114 & 97 & & \\
\hline
\end{tabular}

TITLE-ABS-KEY: title, abstract, keywords. Thus the research was performed looking for the written above words within title, abstract and keywords of the papers in Scopus database. "harvest *": every word which includes "harvest", thus: pre-harvest, post-harvest, harvesting, etc

Findings reported in Table 1 were analyzed to further refine the search and approximately 200 papers were used to build up the present review.

\section{Sunflower}

\subsection{Sunflower Main Features}

Sunflower is an annual plant belonging to Asteraceae family and it is one of the most important oil crop worldwide [72]. Main producing countries are Ukraine and Russian Federation, which approximately account for $50 \%$ of global sunflower production [73]. Contrary to the majority of the other oil crops, sunflower oil is mainly used for human consumption, but it can also be used for biodiesel production [74]. When considering the great importance at global scale of this crop, many different varieties have been selected in order to achieve the possibility of cultivation in different climatic conditions and with different crop management (rainfed, minimum tillage, no tillage, various fertilization rates) [75-77]. Oil content in the seeds ranges between $38 \%$ and $53 \%$ by weight $[75,78-81]$. Sunflower is commonly considered an "environmental friendly" crop [82]; indeed, it generally requires low level of fertilization and the row spacing of about $50 \mathrm{~cm}$ allows for mechanical control of weeds [82]. On the other hand, ploughing resulted in being helpful to ensure the correct development of the tap root [83]. In the last years, there has been growing interest for sunflower cultivation in no tillage or reduced tillage systems [75]. Interesting results under this point of view were showed by Sessiz et al. (2008), who found that seed yield and oil content did not vary between no tillage and conventional tillage management [84].

Sunflower by-products show interesting features for energy production [85-89].

In particular, sunflower cake could be used as feedstock for anaerobic digestion, when considering its $\mathrm{C} / \mathrm{N}$ ratio over 10 [88], for biofuel production in co-pyrolysis [90] or for the production of biomaterials through extrusion process [91]. Sunflower stalks can be used for bio-ethanol and biogas production [92,93] and seed hulls are suitable for energy production in co-firing $[94,95]$. On the contrary, the sunflower cake did not exhibit interesting characteristics for animal feeding [96,97].

\subsection{Sunflower Mechanical Harvesting}

Sunflower harvesting is performed with specific headers (Figure 1) that are designed for collecting sunflower seeds and transporting them to the inclined chamber of the combine harvester. Sunflower headers generally consist of the frame, auger, seed conveyors, choppers stems, dividers, and cutting units [34]; suitable combine settings for sunflower are given in Table 2. 


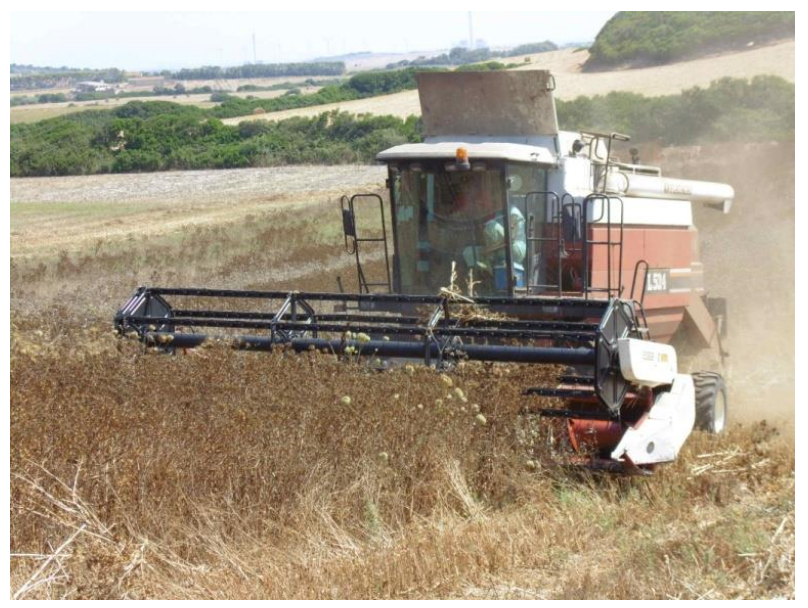

Figure 1. Sunflower header working on cardoon (photo by Authors).

Table 2. Suitable combine harvester setting for sunflower [98].

\begin{tabular}{cc}
\hline Parameter & Values \\
\hline Threshing speed $(\mathrm{rpm})$ & $300-400$ \\
Concave clearance $(\mathrm{mm})$ & $30-40$ \\
Fan speed (rpm) & $650-850$ \\
Upper sieve clearance $(\mathrm{mm})$ & $13-15$ \\
Lower sieve clearance $(\mathrm{mm})$ & $7-9$ \\
\hline
\end{tabular}

The use of sunflower headers is generally associated with values of seed loss of 2\% [34], if considering the average global yield for sunflower in 2018 of $1.97 \mathrm{Mg} \mathrm{ha}^{-1}$ [73], which corresponds, approximately, to $39 \mathrm{~kg} \mathrm{ha}^{-1}$ of lost seed. The working speed of the combine harvester generally ranges from a minimum of $3.80 \mathrm{~km} \mathrm{~h}^{-1}$ to a maximum value of $9.60 \mathrm{~km} \mathrm{~h}^{-1}$ [34]. The field capacity ranges from $1.50 \mathrm{ha} \mathrm{h}^{-1}$ to $3.70 \mathrm{ha} \mathrm{h}^{-1}$ in the case of headers with eight rows; and, from $4.30 \mathrm{ha} \mathrm{h}^{-1}$ to $5.40 \mathrm{ha} \mathrm{h}^{-1}$ for headers having 12 rows. Fuel consumption varies from $6.71 \mathrm{~L} \mathrm{ha}^{-1}$ up to $11.50 \mathrm{~L} \mathrm{ha}^{-1}$ [34].

Three main aspects of the sunflower harvesting stage should be further investigated: the possibility to reduce the loss of seeds, to reduce the impurity of the seeds collected and to manage properly the crop residues. They are mainly made of talks that are usually shredded and buried into the soil in a second passage operation which has economic and environmental impacts (for example causing higher soil compaction) [35,36]. Nalobina et al. 2019 developed a sunflower header to further reduce seed losses and it is able to cut the stalk at a lower height, avoiding clogging of the header through the appliance of a conical rotor for the collection and the cut of stems. This modified header allowed for a reduction of seed loss, even if the working speed was consistently lower $\left(1.00-2.50 \mathrm{~km} \mathrm{~h}^{-1}\right)$ [35].

Startsev et al. (2020) also tried to reduce seeds loss in sunflower mechanical harvesting. Authors developed an auger-reel applied to the header of the combine harvester that allowed for the reduction of seeds loss from the typical value of $2 \%$ up to $0.63 \%$ [37]. In case of dwarf sunflower plants, Shaforostov et al. (2019) designed and presented another prototype whose innovative features permitted the regulation of the inclination (in relation to the soil plate) of the screws along the dividers. In such way, it was possible to adjust the inclination according to the characteristics of the crop (dwarf or tall sunflower), thus allowing to reduce the length of the stem entering the threshing apparatus, which is the main responsible of clogging [38]. The stem of dwarf and tall sunflower measured $15 \mathrm{~cm}$ and $25 \mathrm{~cm}$ in length, respectively, whilst seeds loss of $0.25 \%$ in dwarf plants and $0.98 \%$ in tall plants were reported. The working speed of the combine harvester was set at $5 \mathrm{~km} \mathrm{~h}^{-1}$ for both sunflower varieties [38].

The third issue in sunflower mechanical harvesting, i.e., avoiding/limiting extraneous matter entering in the header, was addressed by Startsev et al. (2020). In particular, the authors developed the 
design of a sieve with additional holes that can be installed as additional cleaning stage in the cleaning shoe of the combine harvester. Those sieve holes were longitudinally shaped, just like sunflower seeds, and they also permitted the adjustment the area according the characteristics of the seeds of cultivar harvested. Such improvements permitted the significant reduction of extraneous material in the hopper heap by $38-42 \%$ by weight, in comparison with a combine harvester not equipped with such particular sieve [39].

However, in the same reference period, the impact of mechanization on agriculture was also investigated. Particularly, some studies focused on soil compactness due to machinery traffic, which is a major concern in both agriculture and forestry mechanization activities [99-104]. Among them, Dalmis et al. (2013) designed a chopper unit that can be installed under the header of a combine harvester and driven by via transmission chain connected to the header. The chopper unit consisted of a main body, a main shaft, three bevel gears mechanisms, four bearings, and three blade modules. The chopping occurred simultaneously to harvesting operation; therefore, avoiding the need for a second operation also saving time, labor, and energy. The height of the stalks on field measured $15 \mathrm{~cm}$ in height on average, which was similar to the average size of the chopped material in typical second passage chopping operation. The additional fuel consumption of the combine harvester due to the chopping unit was reported in $1.001 \mathrm{~h}^{-1}$ [40].

\section{Canola}

\subsection{Canola Main Features}

Canola (or rapeseed or oilseed rape) belongs to Brassicaceae family. It is the most cultivated oil crop worldwide and there has been growing interest on it during the last two decades [105]. The main producing countries are Canada and China, which together account for the $38 \%$ of global production [73]. However, canola is also gaining interest in Mediterranean zone [106]. Like sunflower, canola oil is suitable for human consumption [107,108], although energy production [109-111] is the most relevant application $[106,112]$. The main features that drive the growing importance of canola is the high oil content (about 45-50\%) [113] and suitability for phytoremediation in soils polluted with diesel and heavy metals [114,115]. Moreover, rapeseed by-products can be also exploited. The cake is suitable for fermentation [116], while shoots and leaves are edible for humans, moreover nectar production is suitable from flowers, flavonoids and amino-acids extraction from pollen and fodder can be obtained from straw and seed meal [117]. Scientific research is focusing on the development of varieties and cultivation techniques to improve the possibility of mechanical collection. Rapeseed phenotypes that are suitable for mechanization should exhibit specific traits as: tightness, lodging resistance, collective flowering, and maturation, and produce more pods on the main stem [118,119]. Scientists are tackling the problem by following two strategies: testing higher plantation densities, which have positive effects on those desired traits in mechanical harvesting $[120,121]$ and via developing dwarf cultivars (plant height lower than $160 \mathrm{~cm}$ ) [122,123].

\subsection{Canola Mechanical Harvesting}

Two different options are available for canola harvesting: "direct cut", performed with a combine harvester in a single operation when seed ripeness is reached, or cutting and swathing of the crop at an early stage of ripening in order to limit seed shattering [41,42], and then trashing is performed. Seed loss is generally higher in direct cut method [49], although working performance is better [50] and the soil disturbance is lower. However, differences in seed loss among the two harvesting methods are not always found and a mean value $10 \%$ of seed lost is to be accepted [51-53]. As a general conclusion, it can be stated that combine harvesting is taking over and, currently, it is most studied method reported in the literature. In fact, only Irvine et al. (2010) studied the swathing method applied to canola harvesting [50]. The authors developed an alternative system to swath the crop in order to avoid windrowing operation and limiting the seed loss, which can occur under the strong wind condition. 
The device is made of curved front surface that mechanically bends the plants forward causing the lodging at a height of 10-20 cm above the soil surface. After maturity, the lodged crop is harvested according to the direct-cut methods by operating against the lodging direction. Advantages from such strategy are found in the high working speed of the device and its low purchase cost, particularly if compared with those of a windrower [50]. On the other hand, the possible drawbacks of applying such system could be the delay in the harvesting period as well as the reduction of the speed of the combine harvester due to unavoidable need to cut the plants closer to the soil [50]. However, it is important to underline that, to the best of our knowledge, such a method is not actually applied to substitute the typical swathing one.

Several studies have been focusing on the effects of combine harvesting on seed loss in canola (suitable combine settings are reported in Table 3), and possible solutions to limit such problem are provided accordingly.

Table 3. Suitable combine harvester setting for canola $[54,124]$.

\begin{tabular}{cc}
\hline Parameter & Values \\
\hline Threshing speed $(\mathrm{rpm})$ & $550-580$ \\
Concave clearance $(\mathrm{mm})$ & $35-40$ \\
Fan speed $(\mathrm{rpm})$ & $400-600$ \\
Upper sieve clearance $(\mathrm{mm})$ & $4-16$ \\
Lower sieve clearance $(\mathrm{mm})$ & $3-4$ \\
\hline
\end{tabular}

It is important to highlight that, when it comes to mechanically harvesting the seeds of a given crop, some compromises must be accepted. Firstly, timing is a really important factor that could trigger high seed loss during the harvesting, due to both the natural dehiscence and presence of immature seeds [55]. Moreover, the latter ones are more susceptible to damages [56] and less suitable for high quality biofuel production [43]. Secondly, canola seeds size has negative impact on seeds loss, since smaller seeds can either be lost during impact of the header with tips of the plants, or during the trashing due to airborne effect of the fan [44]. Lastly, because plants are prone to entangle each other, pulling and tearing movements are generated during the harvesting and this can reduce the working efficiency of the machine [45].

So far, three main options for canola combine harvesting are available: using a conventional wheat header [46] without modifications; using wheat header specifically modified [42,47] or using a dedicated header that is characterized by the presence of vertical separators on both sides and by the continuous regulation of the blade-conveyor screw distance [48] (Figure 2). The last two options are meant to reduce pulling and tearing among plants and help to reduce the loss of seeds. When considering the differences in seed morphology between wheat and canola, it is fundamental to adjust the combine harvester set up finely, with particular attention to the fan speed, rotor speed, concave clearance, and sieves choice [46].

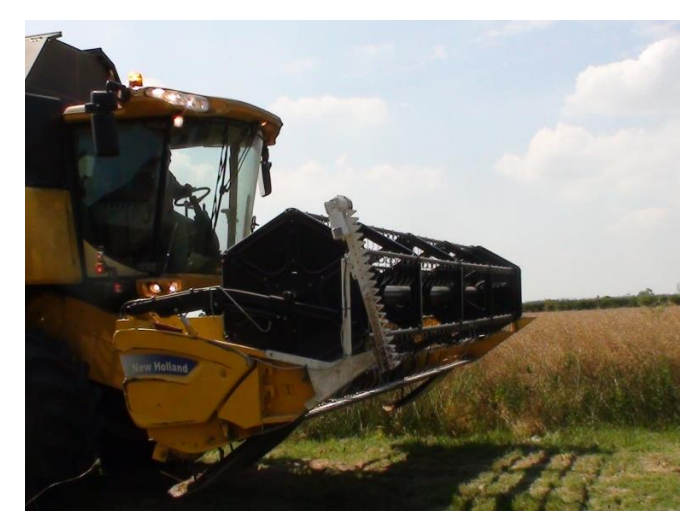

Figure 2. Modified wheat header for canola harvesting (photo by Authors). 
Chronologically, the first study dealing with canola loss in combine harvesting reported in the reference period (2000-2020) is Hobson et al. (2002) [42]. Authors modified a wheat header adding a conveyor between the cutterbar and the auger, which gently conveyed the cut plants to the feeder conveyer, thus reducing the harsh movements partially responsible of seed loss. This modified header showed seed loss of $4.0 \% \mathrm{w} / \mathrm{w}$, while the standard header tested on the same field showed a value of $6-8 \% \mathrm{w} / \mathrm{w}$. According their preliminary economic evaluation, the estimated costs for modifying the header can be leveled off if more than 171 ha year ${ }^{-1}$ over five years period can be harvested, in comparison with using a standard header of the same size [42].

Tests on specific rapeseed header working performance were conducted by Pari et al. (2010) in 2007 and 2009 [48]. In 2007, a comparison between conventional wheat header and specific rapeseed header was performed, whilst in 2009 a wheat header was compared to a modified header bearing a vertical blade on its right side. The lowest value of losses was reached while using a specific rapeseed head in $2007(2.76 \%)$, while wheat head in the same year showed $3.84 \% \mathrm{w} / \mathrm{w}$ of seeds loss. In 2009 , the wheat head showed $9.33 \% \mathrm{w} / \mathrm{w}$ seeds loss while the modified wheat head with vertical blade showed only $6.84 \% \mathrm{w} / \mathrm{w}$ of seeds loss. Referring to the whole width of the combine harvester pass, the quantity of seeds loss found in the middle part (just below the swath) were similar in both treatments. However, the vertical blade applied on the modified header helped to decrease the loss of seeds in the lateral part of pass up to more than $35 \%$. With respect to the combine harvester settings for wheat harvesting, the following tuning has to be applied: $20-30 \%$ lower rotor speed, $15-20 \%$ lower fan speed, $100-150 \%$ higher concave clearance, top riddle screen clearance of 8-10/7-9 mm, and lower riddle screen one of 3-3.5/3.5-4 mm [48]. A similar experiment was conducted by Asoodar et al. (2012), which tested a modified wheat header that was equipped with a vertical cutting bar for seeds loss. The Authors confirmed the previous finding, also reporting a reduction in seeds loss reduction from $14 \% \mathrm{w} / \mathrm{w}$ to $2 \% \mathrm{w} / \mathrm{w}$ [47].

Other tests were further conducted on specific canola header in 2012 by Pari et al. (2012) [54] setting the combine parameters, as explained hereafter: rotor speed $440 \mathrm{rpm}$, fan speed $430 \mathrm{rpm}$, concave clearance $37 \mathrm{~mm}$, upper sieve clearance $4 \mathrm{~mm}$, and lower sieve clearance $3 \mathrm{~mm}$. Such a header showed lower losses in comparison to wheat header $(0.97 \%$ and $1.63 \%$, respectively) [54]. This study also highlighted the importance of the combine harvester speed: when the speed is decreased, the combine harvester is fed more smoothly and the impact of the header on the crop weakens [54]. On the contrary, reducing the speed implies higher costs, since both field capacity and material capacity are lower.

\section{Cardoon}

\subsection{Cardoon Main Features}

Cardoon belongs to the Compositae family, which bears flowers in inflorescences, called capitula or heads. The name of the fruit is cypsela (an achene from an inferior ovary) crowned by plumose filaments, called pappi [125]. Cardoon is cultivated as a multiannual crop and it can reach $2 \mathrm{~m}$ in height. The ecological requirements of $C$. cardunculus suit the environmental conditions of the Mediterranean zone, it requires $450-1000 \mathrm{~mm}_{\text {year }}{ }^{-1}$ of annual rainfall [125], and the cultivation is possible in poor soils [18,126-128]. Cardoon also performs well as bioremediation crop for polluted soils [17,129]. In the Mediterranean area, the establishment of cardoon crops is performed either during autumn or spring [130]. Ploughing and harrowing are recommended in order to allow for the proper development of the root system [131], even if Fernando et al. (2018) highlighted the possibility of cultivating cardoon in no tillage system also demonstrating a reduction in the environmental impact [132]. Cardoon can be either sowed or transplanted, but the first strategy is the most common [133-135]. Plant density is generally $1-2 \mathrm{~m}^{-2}[136,137]$. The harvest is performed in summer from July to September $[134,138,139]$, the yield of whole biomass on dry basis ranges between $10-20 \mathrm{Mg} \mathrm{ha}^{-1}$ year $^{-1}$ with about $500 \mathrm{~mm}$ annual rainfall [125,135]; seeds oil content ranges from $185 \mathrm{~g} \mathrm{~kg}_{\mathrm{dm}^{-1}}$ to $253 \mathrm{~g} \mathrm{~kg}_{\mathrm{dm}}{ }^{-1}$ [140]. 
The cultivation costs of Cynara cardunculus are reported between $329.19 € \mathrm{ha}^{-1}$ and $477.37 € \mathrm{ha}^{-1}$; a consistent share of such costs is represented by biomass collection stage, whilst the harvesting operation accounts for $35-45 \%$ of the total costs [141].

The most interesting aspect of cardoon is the possibility to exploit its biomass in several ways. In the energy sector, the oil seed is suitable for the production of biodiesel [142-144]. The lignocellulosic biomass of the stems can be used as solid biofuel [145] or as substrate for gasification [146], pyrolysis [147], bioethanol production [148], and biomethane [149]. The pappi are particularly suitable for the production of paper pulp $[138,150,151]$. Finally, cardoon exhibits interesting features as a medicinal plant $[152,153]$ or source of food for both humans and animals [154].

\subsection{Cardoon Mechanical Harvesting}

The mechanical harvesting of cardoon can be performed in two different ways. The first one involves the collection of all the aboveground biomass produced and afterward, the separation in different fractions. The second strategy, which is currently the most adopted, involves the use of a combine harvester for separating the seeds from the residual biomass, which is collected successively via baler.

First attempts to apply the first method, e.g., (collection of the whole aboveground biomass), are dated back to the end of 1990's, in Spain. A self-propelled mower-baler and choppers, previously applied to Miscanthus spp harvesting, were tested on cardoon. Unfortunately, the low bulk density of the material (mostly due to the chopper) and the high quantity of pappi scattered around represented a serious problem for the safety and the proper functioning of the machines. Filters and radiators of the machines clogged with a high risk of spontaneous combustion of the biomass [32].

Biomass baling is a more feasible alternative to undertake for a whole biomass harvesting. Here, two passes are needed: the first operation is mowing the plants by using a drum mower, while the second is the baling of the biomass with a round baler. However, during the baling, excessive quantity of soil was picked and included into the bales, thus causing slagging in phase of combustion. A mower-baler towed by a tractor was tested in 2006 in Spain in order to avoid this problem. However, the machine did not perform successfully, mostly due to the very low bulk density of the obtained round bales [32]. The development of high performing machines is a step-by-step process that, relying on specific trials, aims to address all the aspects of the harvesting. First trials were performed in 1990's with using a combine harvester equipped with conventional wheat header, which reported very high loss of seeds, mostly due the different architecture of the cardoon inflorescence as compared to cereal's spikes. Further trials were conducted in 2004 trying to: adjust the height of the header according to the height of the plants, add screens on the header, and lower the speed of the moving parts of the combine harvester. All of the results improved, but the loss of seeds that remained high (35\% approximately) with high percentage of broken achenes (16\%) [31]. Two years later, in Portugal, maize header and a wheat header were tested. Wheat header resulted in a high loss of achenes, but the high cutting height permitted obtaining a satisfactory size of residual biomass for the collection. On the other hand, the maize header showed better performance, but the cutting height of the stalk resulted in being too high and a second pass of lignocellulosic biomass mowing was necessary to collect it, obviously with negative influence on costs [32].

As a consequence of the previous tests that were performed using both maize header and wheat header, in 2007 the first attempt to develop a dedicated header for cardoon mechanical harvesting was made. The prototype derived from the merge of the two: the maize header was brought higher detached the capitula, whilst the wheat header below cut the stalks at the ground level. The residues of the threshed capitula were discharged on the swath, in order to collect them together with the lignocellulosic biomass. The combine harvester that were equipped with this header showed good working productivity with $3.24 \mathrm{~km} \mathrm{~h}^{-1}$ working speed and $1.57 \mathrm{ha} \mathrm{h}^{-1}$ field capacity, but no data concerning seed loss were reported by the authors [57]. The main problem with such header regarded the lower part of the machine, which was developed for a row cultivation, like maize and wheat. 
Cardoon instead is a long-standing crop that is initially set up as row cultivation, but, after the first cut, it loses the row setting thanks to offshooting. Further improvements of the header (Figure 3) aimed to guarantee the cut of the stalk throughout the length of the cutting bar [58]. Working speed of the combine harvester increased to $4.41 \mathrm{~km} \mathrm{~h}^{-1}$ with a field capacity of $2.10 \mathrm{ha} \mathrm{h}^{-1}$ and a material capacity of $1.50 \mathrm{Mg} \mathrm{h}^{-1}$ of harvested seeds and of $13.05 \mathrm{Mg} \mathrm{h}^{-1}$ of lignocellulosic biomass. Biomass loss (seeds included) was $10.70 \%$ and damaged achenes were $3.25 \%$ [155].

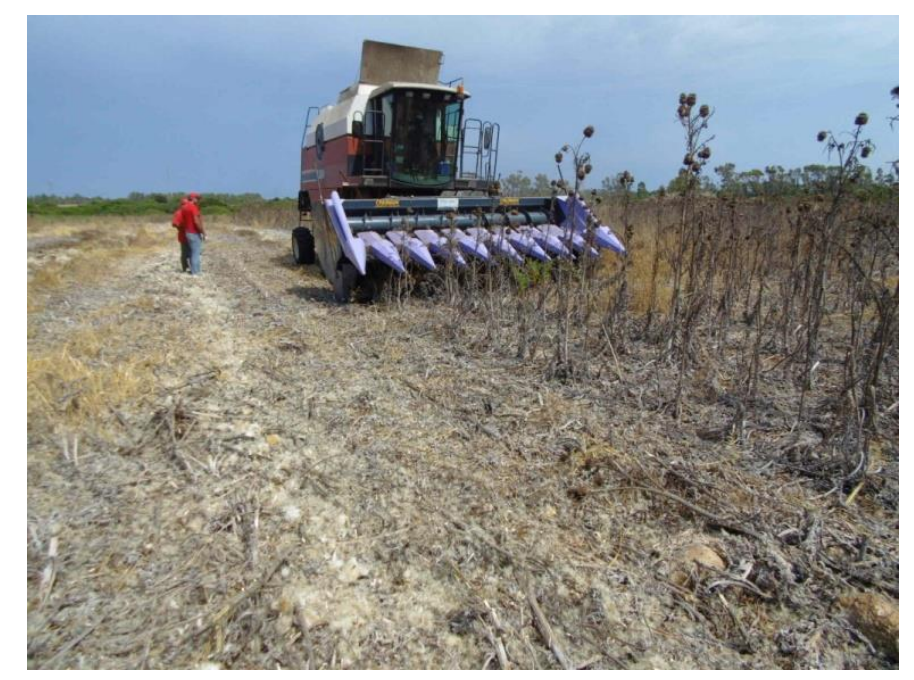

Figure 3. Dedicated header for cardoon harvesting (photo by Authors).

The performance of the prototype was also tested against the performance of two wheat headers: one of the two was modified by adding triangular plates under the cutting bar in order to reduce seeds loss. Therefore, three headers were tested. The field capacity resulted lower in cardoon header (1.27 ha $\left.\mathrm{h}^{-1}\right)$ than in modified wheat header $\left(1.74 \mathrm{ha} \mathrm{h}^{-1}\right)$ and in classical wheat header $\left(1.67 \mathrm{ha} \mathrm{h}^{-1}\right)$. The loss of biomass was lower in the case of cardoon header in comparison with the others. The loss of seed triggered by the cardoon header was $86 \%$ lower in comparison with the conventional wheat header and $65 \%$ lower than the modified header. Moreover, lignocellulosic biomass losses were significantly lower with the cardoon header prototype (about $8 \%$ ) than in the other two headers (more than 50\%) [59].

When it comes to cultivate cardoon on marginal Mediterranean soils, some problems may arise in the case of presence of stones. Stony soils represent a real challenge for mechanical harvesting, since the rocks can clog the combine harvester and cause serious damages to the mechanisms. Additionally, such soils undergo neither tillage nor levelling. Therefore, the driver has to keep the cutting bar distant from the soil in order to avoid unwanted external material within the header. This cautionary maneuver triggers the increase residual biomass loss. The development of a new flexible bar, driven by a system for sensing and signaling the presence of obstacles during the forward of motion of a combine harvester, was realized and tested. This flexible bar performed well, but it is important to highlight that the combine harvester speed was rather low, i.e., $0.70 \mathrm{~km} \mathrm{~h}^{-1}[60,61]$, so further tests and adjustments are encouraged in order to reach a working speed as much as possible close to the working speed of other dedicated headers.

The last mechanical improvement found in literature concerning cardoon crops is the development of a specific system that is able to collect the pappi from the cardoon's flower. During threshing, pappi are discharged along with the residual biomass in swaths for being included in the bales during the baling (within 3-4 h after harvesting). Because of the light weight, they can be quickly blown away from the straw. Thus, in order to limit such phenomenon, the combine harvester was equipped with a wetting system made of a water tank, an electric pump, a flow regulator, and three pairs of nozzles that sprayed the threshed material with a wetting solution. Four adjuvants in two different concentrations were used to extend the retention time. The amount of pappi remaining on the windrow proved the 
efficacy of one of the adjuvants (alkyl polysaccharide at $0.20 \%$ concentration) in limiting dispersal (52.8 $\mathrm{kg} \mathrm{ha}^{-1}$ ), bearing in mind that, without wetting (untreated), the amount remaining was seven times less $\left(7.51 \mathrm{~kg} \mathrm{ha}^{-1}\right)$. Additionally, preliminary economic analysis was conducted, thus proving the economic feasibility of such system [62].

However, it is important to highlight that, notwithstanding the growing interest for cardoon cultivation, no data regarding the setting of the combine harvester are available in literature.

\section{Camelina}

\subsection{Camelina Main Features}

Camelina belongs to Brassicaceae family [156]. This species originated from South-East Europe and South-West Asia [157]. Plant height generally ranges from 65 to $110 \mathrm{~cm}$ [158]. Seeds are contained within silique, commonly called seed capsules or pods, which measure from 5 to $14 \mathrm{~mm}$ in length, pear-shaped, slightly flattened, and contain eight to 15 seeds [159]. They are very small $(0.7 \mathrm{~mm} \times$ $1.5 \mathrm{~mm}$ ), with a 1000-seed weight ranging between 0.8 and $1.8 \mathrm{~g}$, depending on cultivar and growing conditions [160,161]. Seed oil content has been reported to range from $30 \%$ to $49 \%$ [160-163].

Thanks to the availability of both winter and spring varieties and the relatively short life cycle, camelina is particularly suitable for double cropping with small grain cereals, soybean, and sunflower [63,164-169]. Concerning the crop establishment, sowing occurs at a depth of 6-13 mm [159] applying 4 and $6 \mathrm{~kg} \mathrm{ha}^{-1}$ of seeds [170].

The current growing interest in camelina cropping is linked to several factors. Apart from the double cropping, camelina shows high seeds oil content (30-49\%) [171] and multiple uses of it, i.e., biodiesel $[172,173]$ and jet fuel production [174,175], animal feeding [176-178], aquaculture [179,180], raw material for agrochemical products [181], and medical and veterinary applications [182,183]. Moreover, camelina is a low input crop in comparison with most of the commodity crops cultivated for biofuel production [165], so the environmental impact is lower [184], particularly if the suitability of camelina straw for bioenergy purposes is also included $[185,186]$. According to the literature, can be cultivated on poor soils and on soils with difficult conditions, even in the Mediterranean zone [187].

Concerning the economic aspects, some studies reported a breakeven point of biodiesel price lying between $0.88 € 1^{-1}$ to $1.06 € 1^{-1}$ in order to gain profit from the cropping [156,172] and including the cultivation costs of approximately $428.00 € \mathrm{ha}^{-1}$ [188].

\subsection{Camelina Mechanical Harvesting}

Camelina, similarly to canola, is directly combined with traditional wheat header or swathed and then combined. Both of the methods result in similar seed yields [63]. The setting of the combine harvester is to be adapted to the species' features; e.g., speed, wind flow (fan speed), small opening screens, leak sealing, distance between the threshing cylinder, and the concave in order to prevent seed loss [64]. A certain tendency to seed shattering is reported in camelina, although not as much as in rapeseed [159].

Notwithstanding the growing attention of scientific community to such crop, very few studies dealt with mechanical harvesting analysis, setting and improvement.

Sintim et al. (2016) tested seed loss in mechanical harvesting performed with a plot combine harvester, firstly set for canola seeds, and then ongoing adjustments were carried out in order to minimize seeds loss. Seed loss was $11.70 \% \mathrm{w} / \mathrm{w}$ [65]. Another recent study, reported harvesting costs of $46.70 € \mathrm{ha}^{-1}$ in the case of using a combine harvester equipped with wheat header, accounting for the $10 \%$ of the overall cultivation costs [66].

Needless to say, much more should be done about mechanical harvesting topic of this interesting oil crop. 


\section{Safflower}

\subsection{Safflower Main Features}

Safflower (Carthamus tinctorious L.) is an annual oilseed crop. The main producing countries are Kazakhstan and USA, which together account for about the half of the global production [73]. Safflower oil is mainly used for biodiesel production [189] but it can be also used as a heat-stable cooking oil to fry and it is also used in cosmetics, food coatings, animal nutrition, and infant food formulations [69]. This plant has a strong central stem, a varying number of branches, and a taproot system. Each branch usually bears from one to five flower heads containing 15 to 20 seeds each [69]. The seed oil content ranges from $30 \%$ to $50 \%$, depending on the variety and the environmental conditions [190]. Safflower is usually grown in recropping or in rotation with small grains or fallow and annual legumes. This species reaches the physiological maturity about 30 days after flowering and it is ready for the harvesting when most of the leaves have turned brown [69].

Seed shattering is a minor problem, although safflower should be harvested as soon as it is mature to minimize the danger of seed damage from excessive moisture.

Excessive rain and high humidity after physiological maturity of the seed may cause sprouting in the head. Safflower seeds are small, i.e., thousand-grain mass varies from $55.30 \mathrm{~g}$ to $41.30 \mathrm{~g}$ [191]. For a proper seed germination, both ploughing and harrowing are required. Seeding is usually performed in rows with a distance of approximately $45 \mathrm{~cm}$ between rows, and with a plant density of 45,000-60,000 plants per hectare. The high tolerance to drought makes the safflower suitable for cultivation in Mediterranean climate [192].

\subsection{Safflower Mechanical Harvesting}

Safflower harvesting is usually carried out with a combine harvester equipped with wheat header [69]. Literature lacks scientific studies regarding the harvesting of such oil crop. Indeed, only one paper dealing with this issue was found in the framework of the present review.

In particular, Pari et al. (2016) analyzed the mechanical harvesting performance of a wheat header (Figure 4) for safflower seeds collection [192].

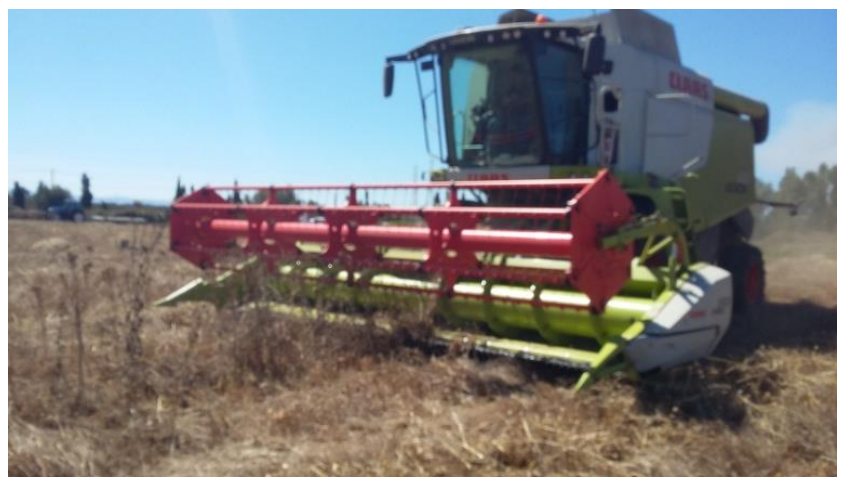

Figure 4. Wheat header collecting safflower seeds (photo by Authors).

Table 4 provides the applied settings of the combine harvester.

Table 4. Suitable combine harvester setting for safflower [192].

\begin{tabular}{cc}
\hline Parameter & Values \\
\hline Threshing speed $(\mathrm{rpm})$ & 800 \\
Concave clearance $(\mathrm{mm})$ & 54 \\
Fan speed $(\mathrm{rpm})$ & 400 \\
Upper sieve clearance $(\mathrm{mm})$ & 11 \\
Lower sieve clearance $(\mathrm{mm})$ & 6 \\
\hline
\end{tabular}


The working speed was equal to $3.7 \mathrm{~km} \mathrm{~h}^{-1}$ and effective field capacity resulted in $1.32 \mathrm{ha} \mathrm{h}^{-1}$. Seed loss analysis showed a value of $3.2 \%$ with $1.7 \%$ damaged seeds and $22.8 \%$ of impurities [192]. According to these results, it is possible to assert the good efficiency of a typical wheat header for the mechanical harvesting of this oil crop.

This is very interesting, because, unlike cardoon, safflower can be easily harvested with a conventional wheat header and applying fine adjustments to the combine harvester. An important feature that helps to promote the double cropping with traditional crops in both Mediterranean and Temperate zones.

\section{Crambe}

\subsection{Crambe Main Features}

Crambe abyssinica Hocst belongs to Brassicaceae family and it is the only cultivated species of Crambe genus [193]. Crambe oil can be used for the production of biodiesel [194,195] and jet fuel [12,14], but it is also suitable for non-energy applications, such as plastic films, adhesives, cosmetics, nylon, thermal insulation, corrosion inhibitors, synthetic rubber, and industrial lubricant [196-198]. After a period of decreasing attention on crambe in European Union [13], mostly due to significant yield variability [199], establishment difficulties linked to low germination energy, capsule persistence, seed dormancy [200,201], and poor interest of crambe cake for animal feeding [202]; in the last year there has been growing interest toward this species, as demonstrated by several European projects [203]. The renewed attention to this crop is related to several factors: low degree days requirement (about 1600) to reach maturity and so feasibility for double cropping [204-206], drought resistance, adaptability to various soil $\mathrm{pH}$ values, no seed shattering, higher dimension of the seed if compared to other oil crops [13], and plant height suitable for mechanical harvesting [207]. Moreover, crambe cultivation shows lower environmental impact than major oil crops, like, for example, canola [208].

\subsection{Crambe Mechanical Harvesting}

Scientific tests on mechanical harvesting of crambe were conducted by the University of Wisconsin in 1991 and University of Nebraska in 1993 [209,210] with conventional combines harvester set as for wheat harvesting. The optimal setting found is: threshing cylinder speed between 400 and $500 \mathrm{rpm}$; concave clearance of $10 \mathrm{~mm}$; and, fan speed $500 \mathrm{rpm}$. The Authors also suggested to keep the frontal reel rotation speed slightly faster than the ground speed of the combine harvester in order to minimized the phenomenon of seed shattering [209,211]. Others studies also support the hypothesis to apply such strategy for crambe mechanical harvesting under the economic point of view, reporting a harvesting cost of approximately $47.00 € \mathrm{ha}^{-1}[66,70]$.

Other studies, which were performed in 2012 with a $1.60 \mathrm{~m}$ wide plot combine harvester, aimed to provide further detailed information regarding the best combine setting. The machine was tested at three different speeds of working $\left(3.0,5.0,8.2 \mathrm{~km} \mathrm{~h}^{-1}\right)$ and four rotation speeds of the threshing cylinder (400, 600, 800, and $1000 \mathrm{rpm})$. According to their findings, the lowest seeds loss, i.e., $3 \% \mathrm{w} / \mathrm{w}$, was experienced when the working speed of the combine harvester is $5.04 \mathrm{~km} \mathrm{~h}^{-1}$ and speed rotation of the threshing cylinder is $800 \mathrm{rpm}$ [71].

In light of what written above, the status of crambe mechanical harvesting is very similar to safflower. In fact, the only possible strategy is through using a combine harvester equipped for wheat harvesting, but set differently. Thus, the possibility to further exploit this oil crop in the future is a tangible option. Table 5 provides suitable settings of the combine harvester. 
Table 5. Suitable combine harvester setting for crambe $[71,209,210]$.

\begin{tabular}{cc}
\hline Parameter & Values \\
\hline Threshing speed (rpm) & $400-800$ \\
Concave clearance (mm) & 10 \\
Fan speed (rpm) & 500 \\
\hline
\end{tabular}

\section{Castor}

\subsection{Castor Main Features}

The world production of castor oil seeds (Ricinus communis L.) increased from 1.19 Mt in 1998 to $1.4 \mathrm{Mt}$ in 2018, with a pick of 2.74 Mt in 2011 [73], highlighting a constant growing interest on this species. India is the most productive country of castor oil (more than $80 \%$ of the worldwide production) along with Mozambique, China, Brazil, Myanmar, Ethiopia, Paraguay and Vietnam [212]. Castor can grow well on marginal lands; it is resistant to drought and pests. The seeds oil content ranges from $35 \%$ to $55 \% \mathrm{w} / \mathrm{w}$ for high yield breed type (more than $1000 \mathrm{~L} \mathrm{ha}^{-1}$ can be obtained when cultivated), has one of the highest viscosities among vegetable oils, and a molecular weight of 298 [213]. Globally, it only accounts for $0.15 \%$ of the total vegetable oil production [214] but it offers a wide spate of possible applications that stretch from pharmaceutical and cosmetic sectors to lubricants and oil-derived products [215]. The obtained bio-oil can also be used as a renewable fuel and chemical feedstock [216]. However, the content of toxic compounds as ricin in castor beans, curbs the possibility to cultivate castor plants extensively. In fact, several cases of accidental or intentional contaminations with ricin have been reported worldwide between 1981 and 2011 [217], although the scientists have never given up on studying this species.

Castor is relatively high demanding in $\mathrm{N}$ requirements when compared with other oil crops, as for instance soybean [209], and nitrogen availability in the soil promotes the expansion of leaves as well as the elongation of the stems [218]. Such effects trigger the development of a considerable amount of aerial biomass, which, in turn, reduces the harvest index of the crop [219].

\subsection{Castor Mechanical Harvesting}

Capsules are harvested when completely dried and a delay in this phase can lead to high seed loss for shattering. Castor seeds yield can reach up to $4.44 \mathrm{Mg} \mathrm{ha}^{-1}$ in the Mediterranean area [220], but the presence of green racemes bearing unripe capsules is a feature that should be reduced. At least, defoliation and fruit ripening must be artificially induced in order to have homogeneity among plants. This represents a big issue to address when it comes to harvesting stage, since more than one pass is mandatory and mechanization is barely possible when the growth is indeterminate $[67,221,222]$. Additionally, the use of chemicals and growth regulators are not allowed in organic farming. Therefore, harvesting is mainly performed manually with negative impact on the supply chain costs. Literature lacks the knowledge of scientific support regarding the possibility to harvest castor seeds mechanically, although unofficial tests have been conducted so far. Combine harvesters that are equipped with modified maize headers are currently used, although fine regulations of the cylinder speed, cylinder-concave clearance are strongly needed in order to reduce as much as possible seeds loss and seed damage (no data about combine harvester setting were found in literature). However, clogging may occur in the case of high quantity of aerial biomass production. The only dedicated header for castor beans harvesting is currently produced by Evogene Ltd. and Fantini s.r.1 which announced in 2018 the successful results obtained: they reported a reduction of seeds loss from the current $50 \%$ to $5 \%$ in two consecutive tests that were performed in 2017 and 2018 on proprietary castor varieties [223]. Combine harvesters are usually equipped with a cutting bar that is situated in the lower part of the header, and it cuts the stem of plants at a given height. Consequently, a certain amount of aerial biomass is conveyed within the cleaning system, which, in the case of castor plants, is not negligible. On the contrary, a different approach is proposed by Zhao et al. (2019), particularly 
reported the possibility to harvest the capsules only, without cutting and threshing the whole plant. The innovative system seeks the use of a vibrating system instead of a cutting bar that is mounted on the header of the combine harvester [68]. Such a strategy is worthy of further investigation in order to provide scientific evidence on the reliability of such strategy. However, the upstanding residual biomass can be further collected if necessary. So far, no other scientific evidences have been found regarding the development of mechanical harvesting machines that are specifically dedicated to castor beans. However, lots of effort has been put in the selection of desirable traits, like dwarf plant type $(<100 \mathrm{~cm})$, early flowering and maturity (26-29 days and 120-140 days, respectively), seeds weight (70-80 g/100 seed), and high oil content (54-55\%) [224].

\section{Discussions and Conclusions}

From the comprehensive analysis of the reviewed literature, the main aspect that stands out is the different degree of mechanical harvesting among herbaceous oil crops. Some of them share common machineries and strategies; sometimes, even specifically developed technologies are available. Others still profoundly lack this availability of a such specific machine that is able to harvest the seeds efficiently. According to the similarities and differences found, it is possible to draw some common conclusions among the reviewed species.

Sunflower and canola are currently being considered among the major herbaceous oil crops, which benefit from a well-developed technology for the seeds harvesting worldwide. Combine harvesters can be equipped with specific headers that can guarantee both high working capacity and low seeds loss. These two aspects concretely contribute to making the cultivation of them economically sustainable for farmers. In fact, the final revenue for farmers of a given crop is already jeopardized by the negative effects of unpredictable biotic factors, like climate and seasonality, and biotic factors, like pests and diseases, which can occur. Therefore, it is very important to rely on very efficient machines that accomplish the harvesting task quickly and effectively.

Significant improvements have been found in cardoon harvesting. In fact, the implementation of the header of the combine harvesters for cardoon seeds harvesting, significantly reduced the amount of seeds lost from $50 \%$ to $3 \%$. Another problem addressed in cardoon cropping, specifically on stony soils, is the presence of stones in the field that compromise the harvesting. The development of a flexible cutting bar that can continuously adjust itself to the terrain pattern represents a valid innovation that is available to farmers. The working speed is still too low, but further research can also improve this aspect too, getting closer and closer to the combine performance known, for example, in sunflower and canola.

Differently, safflower and crambe mechanical harvesting relies on a combine harvester that is equipped with wheat header. The loss of seeds is approximately $3 \%$, which is an acceptable value. This is a very interesting feature for farmers who cultivate cereals. In fact, they could broaden the number of crops cultivated without spending more money on new machineries. However, during the in the last years, the interest on safflower and crambe has not been constant.

Finally, it is possible to consider the mechanical harvesting of both camelina and castor not yet satisfying. They have both shown a fast growing interest in the scientific community, but, on the other hand, very little efforts have been put to the enhancement of specific mechanical harvesting. Several papers and scientific projects have been studying camelina and castor under the agronomic, genetic, and biochemical point of view, but, indeed, very little is known in the possible strategies for mechanical harvesting. Nowadays, contractors borrow the harvesting strategy from other crops (i.e., wheat header for camelina and maize one for castor), which show the major drawback to exhibit high loss of seeds. Additionally, very little is reported about seed loss, work productivity, and harvesting costs in the literature. These are the key issues for the development of efficient supply chains and future scientific research should focus on addressing this. Although the scientific community agrees on using a combine harvester for collecting the seeds, further studies on the possible regulations as well as possible modifications to apply to the machine are strongly needed and encouraged. 
In oil crops cultivation, two major concerns arise: the economic sustainability (the cost of biodiesel production is currently higher than oil-derived diesel) and the competition with food crops for land use. Recently, the cultivation of industrial crops on marginal lands has gained interest throughout the Europe, and ongoing research activities focus on providing scientific evidence on such strategy. However, it is not an easy task to accomplish since the productivity of marginal lands is usually lower. Besides, if the harvesting phase is not effective, the overall strategy is not sustainable under the economic point of view. Hence, it is important to improve the harvesting machines and strategies, along with the genetic and agronomic ameliorations of the oil crops.

Author Contributions: Conceptualization, L.P., F.L., W.S.; methodology, L.P., F.L., W.S.; data curation, F.L. and W.S.; writing-original draft preparation, F.L. and W.S.; writing-review and editing, L.P., F.L., W.S.; supervision, L.P.; funding acquisition, L.P. All authors have read and agreed to the published version of the manuscript.

Funding: This research was funded by Horizon 2020 project MAGIC, grant number 727698.

Acknowledgments: In this section you can acknowledge any support given which is not covered by the author contribution or funding sections. This may include administrative and technical support, or donations in kind (e.g., materials used for experiments).

Conflicts of Interest: The authors declare no conflict of interest.

\section{References}

1. European Union. Renewable Energy Directive 2018/2001/EU. Available online: https://eur-lex.europa.eu/ legal-content/EN/TXT/PDF/?uri=CELEX:32018L2001\&from=EN (accessed on 10 February 2020).

2. Creutzig, F.; Ravindranath, N.H.; Berndes, G.; Bolwig, S.; Bright, R.; Cherubini, F.; Chum, H.; Corbera, E.; Delucchi, M.; Faaij, A. Bioenergy and climate change mitigation: An assessment. Gcb Bioenergy 2014, 7, 916-944. [CrossRef]

3. Suardi, A.; Saia, S.; Stefanoni, W.; Gunnarsson, C.; Sundberg, M.; Pari, L. Admixing Chaff with Straw Increased the Residues Collected without Compromising Machinery Efficiencies. Energies 2020, 13, 1766. [CrossRef]

4. Bergonzoli, S.; Suardi, A.; Rezaie, N.; Alfano, V.; Pari, L. An innovative system for Maize Cob and wheat chaff harvesting: Simultaneous grain and residues collection. Energies 2020, 13, 1256. [CrossRef]

5. Suardi, A.; Latterini, F.; Alfano, V.; Palmieri, N.; Bergonzoli, S.; Pari, L. Analysis of the Work Productivity and Costs of a Stationary Chipper Applied to the Harvesting of Olive Tree Pruning for Bio-Energy Production. Energies 2020, 13, 1359. [CrossRef]

6. Suardi, A.; Latterini, F.; Alfano, V.; Palmieri, N.; Bergonzoli, S.; Karampinis, E.; Kougioumtzis, M.A.; Grammelis, P.; Pari, L. Machine Performance and Hog Fuel Quality Evaluation in Olive Tree Pruning Harvesting Conducted Using a Towed Shredder on Flat and Hilly Fields. Energies 2020, 13, 1713. [CrossRef]

7. Cocco, D.; Deligios, P.A.; Ledda, L.; Sulas, L.; Virdis, A.; Carboni, G. LCA study of oleaginous bioenergy chains in a Mediterranean environment. Energies 2014, 7, 6258-6281. [CrossRef]

8. Dangol, N.; Shrestha, D.S.; Duffield, J.A. Life-cycle energy, GHG and cost comparison of camelina-based biodiesel and biojet fuel. Biofuels 2017, 11, 399-407. [CrossRef]

9. Graß, R.; Heuser, F.; Stülpnagel, R.; Piepho, H.P.; Wachendorf, M. Energy crop production in double-cropping systems: Results from an experiment at seven sites. Eur. J. Agron. 2013, 51, 120-129. [CrossRef]

10. Akbari, G.A.; Heshmati, S.; Soltani, E.; Amini Dehaghi, M. Influence of Seed Priming on Seed Yield, Oil Content and Fatty Acid Composition of Safflower (Carthamus tinctorius L.) Grown Under Water Deficit. Int. J. Plant Prod. 2019, 14, 245-258. [CrossRef]

11. Bušić, A.; Kundas, S.; Morzak, G.; Belskaya, H.; Mardetko, N.; Šantek, M.I.; Komes, D.; Novak, S.; Šantek, B. Recent trends in biodiesel and biogas production. Food Technol. Biotechnol. 2018, 56, 152-173. [CrossRef]

12. Carlsson, A.S. Plant oils as feedstock alternatives to petroleum-A short survey of potential oil crop platforms. Biochimie 2009, 91, 665-670. [CrossRef] [PubMed]

13. Zanetti, F.; Monti, A.; Berti, M.T. Challenges and opportunities for new industrial oilseed crops in EU-27: A review. Ind. Crop. Prod. 2013, 50, 580-595. [CrossRef]

14. Metzger, M.J.; Bunce, R.G.H.; Jongman, R.H.G.; Mücher, C.A.; Watkins, J.W. A climatic stratification of the environment of Europe. Glob. Ecol. Biogeogr. 2005, 14, 549-563. [CrossRef] 
15. FAO. Global Agriculture towards 2050: How to Feed World 2009; FAO: Rome, Italy, 2009.

16. Pandey, V.C. Suitability of Ricinus communis L. cultivation for phytoremediation of fly ash disposal sites. Ecol. Eng. 2013, 57, 336-341. [CrossRef]

17. Llugany, M.; Miralles, R.; Corrales, I.; Barceló, J.; Poschenrieder, C. Cynara cardunculus a potentially useful plant for remediation of soils polluted with cadmium or arsenic. J. Geochem. Explor. 2012, 123, $122-127$. [CrossRef]

18. Mauromicale, G.; Sortino, O.; Pesce, G.R.; Agnello, M.; Mauro, R.P. Suitability of cultivated and wild cardoon as a sustainable bioenergy crop for low input cultivation in low quality Mediterranean soils. Ind. Crop. Prod. 2014, 57, 82-89. [CrossRef]

19. Pavlista, A.D.; Hergert, G.W.; Margheim, J.M.; Isbell, T.A. Growth of spring camelina (Camelina sativa) under deficit irrigation in Western Nebraska. Ind. Crop. Prod. 2016, 83, 118-123. [CrossRef]

20. Schillinger, W.F. Camelina: Long-term cropping systems research in a dry Mediterranean climate. Field Crop. Res. 2019, 235, 87-94. [CrossRef]

21. Christopher, L.P.; Kumar, H.; Zambare, V.P. Enzymatic biodiesel: Challenges and opportunities. Appl. Energy 2014, 119, 497-520.

22. Acampora, A.; Croce, S.; Assirelli, A.; Del Giudice, A.; Spinelli, R.; Suardi, A.; Pari, L. Product contamination and harvesting losses from mechanized recovery of olive tree pruning residues for energy use. Renew. Energy 2013, 53, 350-353.

23. Pecenka, R.; Lenz, H.; Jekayinfa, S.O.; Hoffmann, T. Influence of tree species, harvesting method and storage on energy demand and wood chip quality when chipping poplar, willow and black locust. Agriculture 2020, 10, 116. [CrossRef]

24. Schweier, J.; Blagojević, B.; Venanzi, R.; Latterini, F.; Picchio, R. Sustainability assessment of alternative strip clear cutting operations for wood chip production in renaturalization management of pine stands. Energies 2019, 12, 3306. [CrossRef]

25. Bonfiglio, A.; Esposti, R. Analysing the economy-wide impact of the supply chains activated by a new biomass power plant. The case of cardoon in Sardinia. Bio-Based Appl. Econ. 2016, 5, 5-26. [CrossRef]

26. Cotana, F.; Cavalaglio, G.; Coccia, V.; Petrozzi, A. Energy opportunities from lignocellulosic biomass for a biorefinery case study. Energies 2016, 9, 748. [CrossRef]

27. Špokas, L.; Steponavičius, D.; Žebrauskas, G.; Čiplienè, A.; Bauša, L. Reduction in adverse environmental impacts associated with the operation of combine harvesters during the harvesting of winter oilseed rape. J. Environ. Eng. Landsc. Manag. 2019, 27, 72-81. [CrossRef]

28. Haile, T.A.; Holzapfel, C.B.; Shirtliffe, S.J. Canola genotypes and harvest methods affect seedbank addition. Agron. J. 2014, 106, 236-242. [CrossRef]

29. Fríd, M.; Dolan, A.; Celjak, I.; Filip, M.; Bartos, P. Harvest of cereals and oilseeds rape by combine harvesters New Holland CX 8090 and New Holland CR 9080. Poljopr. Teh. 2017, 42, 19-24.

30. Špokas, L.; Steponavičius, D. Fuel consumption during cereal and rape harvesting and methods of its reduction. J. Food Agric. Environ. 2011, 9, 257-263.

31. Kehayov, D.; Vezirov, C.; Atanasov, A. Some technical aspects of cut height in wheat harvest. Agron. Res. 2004, 2, 181-186.

32. Fernandez, J.; Pari, L.; García Müller, M.; Marquez, L.; Fedrizzi, M.; Curt, M.D. Strategies for the mechanical harvesting of Cynara. In Proceedings of the 15th European Biomass Conference \& Exhibition, Berlin, Germany, 7-11 May 2007.

33. Picchio, R.; Proto, A.R.; Civitarese, V.; Di Marzio, N.; Latterini, F. Recent Contributions of Some Fields of the Electronics in Development of Forest Operations Technologies. Electronics 2019, 8, 1465. [CrossRef]

34. Chaplygin, M.; Bespalova, O.; Podzorova, M. Results of tests of devices for sunflower harvesting in economic conditions. E3S Web Conf. 2019, 126, 00063. [CrossRef]

35. Nalobina, O.O.; Vasylchuk, N.V.; Bundza, O.Z.; Holotiuk, M.V.; Veselovska, N.R.; Zoshchuk, N.V. A new technical solution of a header for sunflower harvesting. INMATEH Agric. Eng. 2019, 58, 129-136.

36. Csanadi, T.; Hamphoff, B. A header for efficient sunflower harvesting Deployment of special sunflower head. VDI Berichte 2007, 2001, 343.

37. Startsev, A.S.; Demin, E.E.; Danilin, A.V.; Vasilyev, O.A.; Terentyev, A.G. Results of the production test of sunflower harvesting attachment with an auger reel. IOP Conf. Ser. Earth Environ. Sci. 2020, 433, 012006. [CrossRef] 
38. Shaforostov, V.D.; Makarov, S.S. The header for a breeding plot combine for sunflower harvesting. Acta Technol. Agric. 2019, 22, 60-63. [CrossRef]

39. Startsev, A.S.; Makarov, S.A.; Nesterov, E.S.; Kazakov, Y.F.; Terentyev, A.G. Comparative evaluation of the operation of a combine harvester with an additional sieve with adjustable holes for sunflower harvesting. IOP Conf. Ser. Earth Environ. Sci. 2020, 433, 012007. [CrossRef]

40. Dalmis, I.S.; Kayisoglu, B.; Bayhan, Y.; Ulger, P.; Toruk, F.; Durgut, F. Development of a chopper unit for chopping of sunflower stalk during harvesting by combine harvester. Bulg. J. Agric. Sci. 2013, 19, 1148-1154.

41. Ogilvy, S.E. The effect of timing of swathing on the quality and yield of winter oilseed rape. Asp. Appl. Biol. 1989, 23, 101-107.

42. Hobson, R.N.; Bruce, D.M. Seed loss when cutting a standing crop of oilseed rape with two types of combine harvester header. Biosyst. Eng. 2002, 81, 281-286. [CrossRef]

43. Kachel-Jakubowska, M.; Szpryngiel, M. Influence on drying condition on quality properties of rapeseed. Int. Agrophys. 2008, 22, 327-331.

44. Pari, L.; Assirelli, A.; Suardi, A.; Civitarese, V.; Del Giudice, A.; Santangelo, E. Seed losses during the harvesting of oilseed rape (Brassica napus L.) at on-farm scale. J. Agric. Eng. 2013, 44, 633-636. [CrossRef]

45. Pari, L.; Assirelli, A.; Suardi, A.; Santangelo, E. The yield losses during oilseed rape (Brassica napus L.) harvesting at on-farm scale in the Italian area. In Proceedings of the 21st European Biomass Conference and Exhibition, Copenaghen, Denmark, 3-7 June 2013; pp. 369-371.

46. Bruce, D.M.; Hobson, R.N.; Morgan, C.L.; Child, R.D. Threshability of shatter-resistant seed pods in oilseed rape. J. Agric. Eng. Res. 2001, 80, 343-350. [CrossRef]

47. Asoodar, A.M.; Izadinia, Y.; Desbiolles, J. Benefits of harvester front extension in reducing canola harvest losses. Int. Agric. Eng. J. 2012, 21, 32-37.

48. Pari, L.; Assirelli, A.; Suardi, A. Evaluation of Brassica napus and Brassica carinata losses during harvesting: Three years of experience. In Proceedings of the 18th European Biomass Conference and Exhibition Proceedings, Lyon, France, 3-7 May 2010; pp. 1790-1793.

49. Vera, C.L.; Downey, R.K.; Woods, S.M.; Raney, J.P.; McGregor, D.I.; Elliott, R.H.; Johnson, E.N. Yield and quality of canola seed as affected by stage of maturity at swathing. Can. J. Plant Sci. 2007, 87, 13-26. [CrossRef]

50. Irvine, B.; Lafond, G.P. Pushing canola instead of windrowing can be a viable alternative. Can. J. Plant Sci. 2010, 90, 145-152. [CrossRef]

51. Gan, Y.; Malhi, S.S.; Brandt, S.A.; McDonald, C.L. Assessment of seed shattering resistance and yield loss in five oilseed crops. Can. J. Plant Sci. 2008, 88, 267-270. [CrossRef]

52. Haile, T.A.; Gulden, R.H.; Shirtliffe, S.J. On-farm seed loss does not differ between windrowed and direct-harvested canola. Can. J. Plant Sci. 2014, 94, 785-789. [CrossRef]

53. Zhang, C.L.; Jun, L.I.; Zhang, M.H.; Cheng, Y.G.; Li, G.M.; Zhang, S.J. Mechanical Harvesting Effects on Seed Yield Loss, Quality Traits and Profitability of Winter Oilseed Rape (Brassica napus L.). J. Integr. Agric. 2012, 11, 1297-1304. [CrossRef]

54. Pari, L.; Assirelli, A.; Suardi, A.; Civitarese, V.; Del Giudice, A.; Costa, C.; Santangelo, E. The harvest of oilseed rape (Brassica napus L.): The effective yield losses at on-farm scale in the Italian area. Biomass Bioenergy 2012, 46, 453-458. [CrossRef]

55. Szpryngiel, M.; Wesołowski, M.; Szot, B. Economical technology of rape seed harvest. TEKA Kom. Motoryz. Energ. Rol. Pol. Akad. Nauk Oddział Lublin. 2004, 4, 19-29.

56. Szwed, G.; Lukaszuk, J. Effect of rapeseed and wheat kernel moisture on impact damage. Int. Agrophys. 2007, 21, 299-304.

57. Pari, L.; Fedrizzi, M.; Gallucci, F. Cynara cardunculus exploitation for energy applications: Development of a combine head for thesing and concurrent residues collecting and utilization. In Proceedings of the 16th European Biomass Conference \& Exhibition, Valencia, Spain, 2-6 June 2008.

58. Pari, L.; Sissot, F.; Giannini, E. European Union Research Project Biocard: Mechanization Activities Results. In Proceedings of the Technology and Management to Increase the Efficiency in Sustainable Agricultural Systems, Rosario, Argentina, 1-4 September 2009. 
59. Pari, L.; Alfano, V.; Acampora, A.; Del Giudice, A.; Scarfone, A.; Sanzone, E. Harvesting and Separation of Different Plant Fractions in Cynara cardunculus L. In Perennial Biomass Crops for a Resource-Constrained World; Barth, S., Murphy-Bokern, D., Kalinina, O., Taylor, G., Jones, M., Eds.; Springer International Publishing: Cham, Switzerland, 2016; pp. 261-271.

60. Pari, L.; Del Giudice, A.; Pochi, D.; Gallucci, F.; Santangelo, E. An innovative flexible head for the harvesting of cardoon (Cynara cardunculus L.) in stony lands. Ind. Crop. Prod. 2016, 94, 471-479. [CrossRef]

61. Pari, L.; Giudice, A.D.; Pochi, D.; Francesco, G.; Alfano, V.; Bergonzoli, S.; Santangelo, E. Use of a flexible bar in stony soil. In Proceedings of the 25th European Biomass Conference and Exhibition, Stockholm, Sweden, 12-15 June 2017; pp. 286-288.

62. Pari, L.; Alfano, V.; Mattei, P.; Santangelo, E. Pappi of cardoon (Cynara cardunculus L.): The use of wetting during the harvesting aimed at recovering for the biorefinery. Ind. Crop. Prod. 2017, 108, 722-728. [CrossRef]

63. Gesch, R.W.; Archer, D.W.; Berti, M.T. Dual cropping winter camelina with soybean in the northern corn belt. Agron. J. 2014, 106, 1735-1745. [CrossRef]

64. Obour, K.A. Oilseed Camelina (Camelina sativa L. Crantz): Production Systems, Prospects and Challenges in the USA Great Plains. Adv. Plants Agric. Res. 2015, 2. [CrossRef]

65. Sintim, H.Y.; Zheljazkov, V.D.; Obour, A.K.; Garcia y Garcia, A. Managing harvest time to control pod shattering in oilseed camelina. Agron. J. 2016, 108, 656-661. [CrossRef]

66. Stolarski, M.J.; Krzyżaniak, M.; Tworkowski, J.; Załuski, D.; Kwiatkowski, J.; Szczukowski, S. Camelina and crambe production - Energy efficiency indices depending on nitrogen fertilizer application. Ind. Crop. Prod. 2019, 137, 386-395. [CrossRef]

67. Severino, L.S.; Auld, D.L.; Baldanzi, M.; Cândido, M.J.D.; Chen, G.; Crosby, W.; Tan, D.; He, X.; Lakshmamma, P.; Lavanya, C.; et al. A review on the challenges for increased production of castor. Agron. J. 2012, 104, 853-880. [CrossRef]

68. Zhao, H.; Zhang, C.; Zhao, H. Analysis on The Research Status and Structure Characteristics of Castor Harvester. In Proceedings of the 2019 IEEE International Conference on Mechatronics and Automation (ICMA), Tianjin, China, 4-7 August 2019; pp. 415-420.

69. Berglund, D.; Riveland, N.; Bergman, J. Safflower production. NDSU Ext. Serv. Publ. 2019, 870, 4.

70. Stolarski, M.J.; Krzyżaniak, M.; Kwiatkowski, J.; Tworkowski, J.; Szczukowski, S. Energy and economic efficiency of camelina and crambe biomass production on a large-scale farm in north-eastern Poland. Energy 2018, 150, 770-780. [CrossRef]

71. Reginato, P. Colheita Mecanizada de Sementes de Crambe (Crambe abyssinica L.) no Cerrado sul Mato Grossense. Ph.D. Thesis, Universidade Federal da Grande Dourados, Dourados, Brazil, 2014.

72. Cruvinel, W.S.; Costa, K.A.D.P.; Da Silva, A.G.; Severiano, E.D.C.; Ribeiro, M.G. Intercropping of sunflower with Brachiaria brizantha cultivars during two sowing seasons in the interim harvest. Semin. Agrar. 2017, 38, 3173-3191. [CrossRef]

73. FAO. FAOSTAT Agriculture Data. Available online: http://www.fao.org/faostat/en/\#data (accessed on 20 January 2020).

74. Dos Santos, E.R.; Barros, H.B.; Capone, A.; Ferraz, E.; Fidelis, R.R. Efeito de épocas de semeadura sobre cultivares de girassol, no Sul do Estado do Tocantins. Rev. Ciênc. Agron. 2012, 43, 199-206. [CrossRef]

75. Martinez-Force, E.; Dunford, N.T.; Salas, J.J. 2015 Sunflower: Chemistry Production, Processing and Utilization; AOCS Press: Urbana, IL, USA, 2015.

76. Nouraein, M.; Skataric, G.; Spalevic, V.; Dudic, B.; Gregus, M. Short-term effects of tillage intensity and fertilization on sunflower yield, achene quality, and soil physicochemical properties under semi-arid conditions. Appl. Sci. 2019, 9, 5482. [CrossRef]

77. Soleymani, A.; Shayanfar, M.; Golparvar, A.R.; Shahrajabian, M.H.; Naranjani, L. Response of different sunflower cultivars to various planting densities. Res. Crop. 2011, 12, 134-138.

78. Cosentino, S.L.; Copani, V.; Patanè, C.; Mantineo, M.; D'Agosta, G.M. Agronomic, energetic and environmental aspects of biomass energy crops suitable for Italian environments. Ital. J. Agron. 2008, 3, 81-95. [CrossRef]

79. Anastasi, U.; Cammarata, M.; Sortino, O.; Abbate, V. Comportamento agronomico e composizione lipidica degli acheni di due ibridi di girasole (convenzionale e ad alto oleico) in risposta ai fattori ambientali. Riv. Agron. 2001, 35, 83-93.

80. Monotti, M.; Laureti, D. Il panorama varietale del girasole alto oleico. Agroindustria 2005, 4, 61-70. 
81. Baldini, M.; Turi, M.; Giovanardi, R. Confronto tra sistemi colturali a ridotto impatto ambientale per il girasole destinato alla produzione di biodiesel. Agroindustria 2005, 4, 71-79.

82. Debaeke, P.; Bedoussac, L.; Bonnet, C.; Bret-Mestries, E.; Seassau, C.; Gavaland, A.; Raffaillac, D.; Tribouillois, H.; Véricel, G.; Justes, E. Sunflower crop: Environmental-friendly and agroecological. Oilseeds Fats Crop. Lipids 2017, 24, D304. [CrossRef]

83. Lecomte, V. Difficile de trop simplier en tournesol. Perspect. Agric. 2013, 402, 50-54.

84. Sessiz, A.; Sogut, T.; Alp, A.; Esgici, R. Tillage effects on sunflower (Helianthus annuus L.) emergence, yield, quality, and fuel consumption in double cropping system. J. Cent. Eur. Agric. 2008, 9, 697-710.

85. Kovacic, D.; Kralik, D.; Rupcic, S.; Jovicic, D.; Spajic, R.; Tišmac, M. Soybean straw, corn stover and sunflower stalk as possible substrates for biogas production in Croatia: A review. Chem. Biochem. Eng. Q. 2017, 31, 187-198. [CrossRef]

86. Binder, J.B.; Raines, R.T. Fermentable sugars by chemical hydrolysis of biomass. Proc. Natl. Acad. Sci. USA 2010, 107, 4516-4521. [CrossRef] [PubMed]

87. Perea-Moreno, M.A.; Manzano-Agugliaro, F.; Perea-Moreno, A.J. Sustainable energy based on sunflower seed husk boiler for residential buildings. Sustainability 2018, 10, 3407. [CrossRef]

88. Pedretti, E.F.; Del Gatto, A.; Pieri, S.; Mangoni, L.; Ilari, A.; Mancini, M.; Feliciangeli, G.; Leoni, E.; Toscano, G.; Duca, D. Experimental study to support local sunflower oil chains: Production of cold pressed oil in Central Italy. Agriculture 2019, 9, 231. [CrossRef]

89. Duca, D.; Toscano, G.; Riva, G.; Mengarelli, C.; Rossini, G.; Pizzi, A.; Del Gatto, A.; Pedretti, E.F. Quality of residues of the biodiesel chain in the energy field. Ind. Crop. Prod. 2015, 75, 91-97. [CrossRef]

90. Shie, J.-L.; Chang, C.-C.; Chang, C.-Y.; Tzeng, C.-C.; Wu, C.-Y.; Lin, K.-L.; Tseng, J.-Y.; Yuan, M.-H.; Li, H.-Y.; Kuo, C.-H. Co-pyrolysis of sunflower-oil cake with potassium carbonate and zinc oxide using plasma torch to produce bio-fuels. Bioresour. Technol. 2011, 102, 11011-11017. [CrossRef]

91. Rouilly, A.; Orliac, O.; Silvestre, F.; Rigal, L. New natural injection-moldable composite material from sunflower oil cake. Bioresour. Technol. 2006, 97, 553-561. [CrossRef]

92. Nargotra, P.; Sharma, V.; Gupta, M.; Kour, S.; Bajaj, B.K. Application of ionic liquid and alkali pretreatment for enhancing saccharification of sunflower stalk biomass for potential biofuel-ethanol production. Bioresour. Technol. 2018, 267, 560-568. [CrossRef]

93. Hesami, S.M.; Zilouei, H.; Karimi, K.; Asadinezhad, A. Enhanced biogas production from sunflower stalks using hydrothermal and organosolv pretreatment. Ind. Crop. Prod. 2015, 76, 449-455. [CrossRef]

94. Raclavska, H.; Juchelkova, D.; Roubicek, V.; Matysek, D. Energy utilisation of biowaste-Sunflower-seed hulls for co-firing with coal. Fuel Process. Technol. 2011, 92, 13-20. [CrossRef]

95. Matin, A.; Majdak, T.; Krička, T.; Grubor, M. Valorization of sunflower husk after seeds convection drying for solid fuel production. J. Cent. Eur. Agric. 2019, 20, 389-401. [CrossRef]

96. Casoni, A.I.; Bidegain, M.; Cubitto, M.A.; Curvetto, N.; Volpe, M.A. Pyrolysis of sunflower seed hulls for obtaining bio-oils. Bioresour. Technol. 2015, 177, 406-409. [CrossRef] [PubMed]

97. Xazela, N.M.; Chimonyo, M.; Muchenje, V.; Marume, U. Effect of sunflower cake supplementation on meat quality of indigenous goat genotypes of South Africa. Meat Sci. 2012, 90, 204-208.

98. John Deere Combine Setting Manual. Available online: http://manuals.deere.com/omview/OMHXE13769_ 19/OUO6075_00003C2_19_25JUN09_1.htm (accessed on 16 July 2020).

99. Piron, D.; Boizard, H.; Heddadj, D.; Pérès, G.; Hallaire, V.; Cluzeau, D. Indicators of earthworm bioturbation to improve visual assessment of soil structure. Soil Tillage Res. 2017, 173, 53-63. [CrossRef]

100. Venanzi, R.; Picchio, R.; Grigolato, S.; Latterini, F. Soil and forest regeneration after different extraction methods in coppice forests. For. Ecol. Manag. 2019, 454. [CrossRef]

101. Bodaghi, A.I.; Nikooy, M.; Naghdi, R.; Venanzi, R.; Latterini, F.; Tavankar, F.; Picchio, R. Ground-based extraction on salvage logging in two high forests: A productivity and cost analysis. Forests 2018, 9, 729. [CrossRef]

102. Picchio, R.; Venanzi, R.; Tavankar, F.; Luchenti, I.; Iranparast Bodaghi, A.; Latterini, F.; Nikooy, M.; Di Marzio, N.; Naghdi, R. Changes in soil parameters of forests after windstorms and timber extraction. Eur. J. For. Res. 2019, 138, 875-888. [CrossRef]

103. Picchio, R.; Latterini, F.; Mederski, P.S.; Venanzi, R.; Karaszewski, Z.; Bembenek, M.; Croce, M. Comparing accuracy of three methods based on the gis environment for determining winching areas. Electronics 2019, 8, 53. [CrossRef] 
104. Botta, G.F.; Tolón-Becerra, A.; Bienvenido, F.; Rivero, D.; Laureda, D.A.; Ezquerra-Canalejo, A.; Contessotto, E.E. Sunflower (Helianthus annuus L.) harvest: Tractor and grain chaser traffic effects on soil compaction and crop yields. Land Degrad. Dev. 2018, 29, 4252-4261. [CrossRef]

105. Vicianová, M.; Ducsay, L.; Ryant, P.; Provazník, M.; Zapletalová, A.; Slepčan, M. Oilseed rape (Brassica Napus L.) nutrition by nitrogen and phosphorus and its effect on yield of seed, oil and higher fatty acids content. Acta Univ. Agric. Silvic. Mendel. Brun. 2020, 68, 129-136. [CrossRef]

106. Licata, M.; La Bella, S.; Lazzeri, L.; Matteo, R.; Leto, C.; Massaro, F.; Tuttolomondo, T. Agricultural feedstocks of two Brassica oilseed crops and energy cogeneration with pure vegetable oil for a sustainable short agro-energy chain in Sicily (Italy). Ind. Crop. Prod. 2018, 117, 140-148. [CrossRef]

107. El Sabagh, A.; Hossain, A.; Barutçular, C.; Islam, M.S.; Ratnasekera, D.; Kumar, N.; Meena, R.S.; Gharib, H.S.; Saneoka, H.; da Silva, J.A.T. Drought and salinity stress management for higher and sustainable canola (Brassica napus L.) production: A critical review. Aust. J. Crop Sci. 2019, 13, 88-97. [CrossRef]

108. Chew, S.C. Cold-pressed rapeseed (Brassica napus) oil: Chemistry and functionality. Food Res. Int. 2020, 131, 108997. [CrossRef] [PubMed]

109. D'Avino, L.; Dainelli, R.; Lazzeri, L.; Spugnoli, P. The role of co-products in biorefinery sustainability: Energy allocation versus substitution method in rapeseed and carinata biodiesel chains. J. Clean. Prod. 2015, 94, 108-115. [CrossRef]

110. Karimi Alavijeh, M.; Yaghmaei, S. Biochemical production of bioenergy from agricultural crops and residue in Iran. Waste Manag. 2016, 52, 375-394. [CrossRef]

111. Muszyński, S.; Sujak, A.; Stępniewski, A.; Kornarzyński, K.; Ejtel, M.; Kowal, N.; Tomczyk-Warunek, A.; Szczeniak, E.; Tomczyńska-Mleko, M.; Mleko, S. Surface tension and wetting properties of rapeseed oil to biofuel conversion by-products. Int. Agrophys. 2018, 32, 247-252. [CrossRef]

112. Palmieri, N.; Forleo, M.B.; Suardi, A.; Coaloa, D.; Pari, L. Rapeseed for energy production: Environmental impacts and cultivation methods. Biomass Bioenergy 2014, 69, 1-11. [CrossRef]

113. Gesch, R.W.; Isbell, T.A.; Oblath, E.A.; Allen, B.L.; Archer, D.W.; Brown, J.; Hatfield, J.L.; Jabro, J.D.; Kiniry, J.R.; Long, D.S.; et al. Comparison of several Brassica species in the north central U.S. for potential jet fuel feedstock. Ind. Crop. Prod. 2015, 75, 2-7. [CrossRef]

114. Yang, Y.; Zhou, X.; Tie, B.; Peng, L.; Li, H.; Wang, K.; Zeng, Q. Comparison of three types of oil crop rotation systems for effective use and remediation of heavy metal contaminated agricultural soil. Chemosphere 2017, 188, 148-156. [CrossRef]

115. Lacalle, R.G.; Gómez-Sagasti, M.T.; Artetxe, U.; Garbisu, C.; Becerril, J.M. Brassica napus has a key role in the recovery of the health of soils contaminated with metals and diesel by rhizoremediation. Sci. Total Environ. 2018, 618, 347-356. [CrossRef] [PubMed]

116. De Castro, A.M.; dos Reis Castilho, L.; Freire, D.M.G. Characterization of babassu, canola, castor seed and sunflower residual cakes for use as raw materials for fermentation processes. Ind. Crop. Prod. 2016, 83, 140-148. [CrossRef]

117. FU, D.; Jiang, L.; Mason, A.S.; Xiao, M.; Zhu, L.; Li, L.; Zhou, Q.; Shen, C.; Huang, C. Research progress and strategies for multifunctional rapeseed: A case study of China. J. Integr. Agric. 2016, 15, 1673-1684. [CrossRef]

118. Li, Y.S.; Yu, C.B.; Zhu, S.; Xie, L.H.; Hu, X.J.; Liao, X.; Liao, X.S.; Che, Z. High planting density benefits to mechanized harvest and nitrogen application rates of oilseed rape (Brassica napus L.). Soil Sci. Plant Nutr. 2014, 60, 384-392. [CrossRef]

119. Khan, S.; Anwar, S.; Kuai, J.; Noman, A.; Shahid, M.; Din, M.; Ali, A.; Zhou, G. Alteration in yield and oil quality traits of winter rapeseed by lodging at different planting density and nitrogen rates. Sci. Rep. 2018, 8, 1-12. [CrossRef]

120. Li, X.; Zuo, Q.; Chang, H.; Bai, G.; Kuai, J.; Zhou, G. Higher density planting benefits mechanical harvesting of rapeseed in the Yangtze River Basin of China. Field Crop. Res. 2018, 218, 97-105. [CrossRef]

121. Kuai, J.; Sun, Y.; Zuo, Q.; Huang, H.; Liao, Q.; Wu, C.; Lu, J.; Wu, J.; Zhou, G. The yield of mechanically harvested rapeseed (Brassica napus L.) can be increased by optimum plant density and row spacing. Sci. Rep. 2015, 5, 1-14. [CrossRef]

122. Miersch, S.; Gertz, A.; Breuer, F.; Schierholt, A.; Becker, H.C. Influence of the semi-dwarf growth type on seed yield and agronomic parameters at low and high nitrogen fertilization in winter oilseed rape. Crop Sci. 2016, 56, 1573-1585. [CrossRef] 
123. Hu, Q.; Hua, W.; Yin, Y.; Zhang, X.; Liu, L.; Shi, J.; Zhao, Y.; Qin, L.; Chen, C.; Wang, H. Rapeseed research and production in China. Crop J. 2017, 5, 127-135. [CrossRef]

124. New Holland Combine TX36 Evaluation Report. Available online: https://open.alberta.ca/dataset/d62d2f3e99bb-49c7-9adb-b31b42f61cb2/resource/ac1a629a-2b74-4f38-8586-68156e8b1f14/download/676-afmrc.pdf (accessed on 16 July 2020).

125. Gominho, J.; Curt, M.D.; Lourenço, A.; Fernández, J.; Pereira, H. Cynara cardunculus L. as a biomass and multi-purpose crop: A review of 30 years of research. Biomass Bioenergy 2018, 109, 257-275. [CrossRef]

126. Vasilakoglou, I.; Dhima, K. Potential of two cardoon varieties to produce biomass and oil under reduced irrigation and weed control inputs. Biomass Bioenergy 2014, 63, 177-186. [CrossRef]

127. Mauro, R.P.; Sortino, O.; Pesce, G.R.; Agnello, M.; Lombardo, S.; Pandino, G.; Mauromicale, G. Exploitability of cultivated and wild cardoon as long-term, low-input energy crops. Ital. J. Agron. 2015, 10, 44-46. [CrossRef]

128. Velez, Z.; Campinho, M.A.; Guerra, Â.R.; García, L.; Ramos, P.; Guerreiro, O.; Felício, L.; Schmitt, F.; Duarte, M. Biological characterization of Cynara cardunculus L. Methanolic extracts: Antioxidant, anti-proliferative, anti-migratory and anti-angiogenic activities. Agriculture 2012, 2, 472-492. [CrossRef]

129. Domínguez, M.T.; Montiel-Rozas, M.M.; Madejón, P.; Diaz, M.J.; Madejón, E. The potential of native species as bioenergy crops on trace-element contaminated Mediterranean lands. Sci. Total Environ. 2017, 590-591, 29-39. [CrossRef] [PubMed]

130. Sanz, M.; Mauri, P.V.; Curt, M.D.; Sánchez, J.; García-Müller, M.; Plaza, A.; Fernández, J. Effect of plant density on biomass yield of Cynara cardunculus. Acta Hortic. 2016, 1147, 385-391. [CrossRef]

131. Angelini, L.G.; Ceccarini, L.; o Di Nasso, N.N.; Bonari, E. Long-term evaluation of biomass production and quality of two cardoon (Cynara cardunculus L.) cultivars for energy use. Biomass Bioenergy 2009, 33, 810-816. [CrossRef]

132. Fernando, A.L.; Costa, J.; Barbosa, B.; Monti, A.; Rettenmaier, N. Environmental impact assessment of perennial crops cultivation on marginal soils in the Mediterranean Region. Biomass Bioenergy 2018, 111, 174-186. [CrossRef]

133. Bolohan, C.; Marin, D.I.; Mihalache, M.; Ilie, L.; Oprea, A.C. Research on Cynara cardunculus L. species under the conditions of southeastern Romania area. Sci. Paper Ser. A Agron. 2013, 56, 429-432.

134. Francaviglia, R.; Bruno, A.; Falcucci, M.; Farina, R.; Renzi, G.; Russo, D.E.; Sepe, L.; Neri, U. Yields and quality of Cynara cardunculus L. wild and cultivated cardoon genotypes. A case study from a marginal land in Central Italy. Eur. J. Agron. 2016, 72, 10-19. [CrossRef]

135. Fernández, J.; Curt, M.D.; Aguado, P.L. Industrial applications of Cynara cardunculus L. for energy and other uses. Ind. Crop. Prod. 2006, 24, 222-229. [CrossRef]

136. Curt, M.D.; Sánchez, G.; Fernández, J. The potential of Cynara cardunculus L. for seed oil production in a perennial cultivation system. Biomass Bioenergy 2002, 23, 33-46. [CrossRef]

137. Lag-Brotons, A.; Gómez, I.; Navarro-Pedreño, J.; Mayoral, A.M.; Curt, M.D. Sewage sludge compost use in bioenergy production-a case study on the effects on Cynara cardunculus L energy crop. J. Clean. Prod. 2014, 79, 32-40. [CrossRef]

138. Gominho, J.; Lourenço, A.; Palma, P.; Lourenço, M.E.; Curt, M.D.; Fernández, J.; Pereira, H. Large scale cultivation of Cynara cardunculus L. for biomass production-A case study. Ind. Crop. Prod. 2011, 33, 1-6. [CrossRef]

139. Solano, M.L.; Manzanedo, E.; Concheso, R.; Curt, M.D.; Sanz, M.; Fernández, J. Potassium fertilisation and the thermal behaviour of Cynara cardunculus L. Biomass Bioenergy 2010, 34, 1487-1494. [CrossRef]

140. Raccuia, S.A.; Piscioneri, I.; Sharma, N.; Melilli, M.G. Genetic variability in Cynara cardunculus L. domestic and wild types for grain oil production and fatty acids composition. Biomass Bioenergy 2011, 35, 3167-3173. [CrossRef]

141. Lago, C.; Herrera, I.; Sanchez, J.; Lechon, Y.; Curt, M.D. Environmental and economic assesment of Cynara cardunculus for local bioenergy production under rainfed conditions in the context of climate change impact. In Proceedings of the 27th European Biomass Conference and Exhibition, Lisbon, Portugal, 27-30 May 2019; pp. 1719-1724.

142. Sengo, I.; Gominho, J.; D’Orey, L.; Martins, M.; D’Almeida-Duarte, E.; Pereira, H.; Ferreira-Dias, S. Response surface modeling and optimization of biodiesel production from Cynara cardunculus oil. Eur. J. Lipid Sci. Technol. 2010, 112, 310-320. [CrossRef] 
143. Alexandre, A.; Dias, A.M.A.; Seabra, I.J.; Portugal, A.; De Sousa, H.C.; Braga, M.E.M. Biodiesel obtained from supercritical carbon dioxide oil of Cynara cardunculus L. J. Supercrit. Fluids 2012, 68, 52-63. [CrossRef]

144. Mancini, M.; Lanza Volpe, M.; Gatti, B.; Malik, Y.; Moreno, A.C.; Leskovar, D.; Cravero, V. Characterization of cardoon accessions as feedstock for biodiesel production. Fuel 2019, 235, 1287-1293. [CrossRef]

145. Gil, M.; Arauzo, I.; Teruel, E.; Bartolomé, C. Milling and handling Cynara Cardunculus L. for use as solid biofuel: Experimental tests. Biomass Bioenergy 2012, 41, 145-156. [CrossRef]

146. Encinar, J.M.; Gonzalez, J.F.; Rodriguez, J.J.; Tejedor, A. Biodiesel fuels from vegetable oils: Transesterification of Cynara c ardunculus L. oils with ethanol. Energy Fuels 2002, 16, 443-450. [CrossRef]

147. Encinar, J.M.; Gonzalez, J.F.; Gonzalez, J. Fixed-bed pyrolysis of Cynara cardunculus L. Product yields and compositions. Fuel Process. Technol. 2000, 68, 209-222. [CrossRef]

148. Ballesteros, M.; Negro, M.J.; Manzanares, P.; Ballesteros, I.; Sáez, F.; Oliva, J.M. Fractionation of Cynara cardunculus (cardoon) biomass by dilute-acid pretreatment. In Applied Biochemistry and Biotecnology; Humana Press: Totowa, NJ, USA, 2007; pp. 239-252.

149. Kalamaras, S.D.; Kotsopoulos, T.A. Anaerobic co-digestion of cattle manure and alternative crops for the substitution of maize in South Europe. Bioresour. Technol. 2014, 172, 68-75. [CrossRef] [PubMed]

150. Gominho, J.; Lourenço, A.; Curt, M.; Fernández, J.; Pereira, H. Characterization of hairs and pappi from Cynara cardunculus capitula and their suitability for paper production. Ind. Crop. Prod. 2009, 29, 116-125. [CrossRef]

151. Coccia, V.; Cotana, F.; Cavalaglio, G.; Gelosia, M.; Petrozzi, A. Cellulose nanocrystals obtained from Cynara cardunculus and their application in the paper industry. Sustainability 2014, 6, 5252-5264. [CrossRef]

152. De Falco, B.; Incerti, G.; Amato, M.; Lanzotti, V. Artichoke: Botanical, agronomical, phytochemical, and pharmacological overview. Phytochem. Rev. 2015, 14, 993-1018. [CrossRef]

153. Pandino, G.; Lombardo, S.; Mauro, R.P.; Mauromicale, G. Variation in polyphenol profile and head morphology among clones of globe artichoke selected from a landrace. Sci. Hortic. 2012, 138, 259-265. [CrossRef]

154. Cajarville, C.; González, J.; Repetto, J.L.; Rodríguez, C.A.; Martínez, A. Nutritive value of green forage and crop by-products of Cynara cardunculus. Ann. Zootech. 1999, 48, 353-365. [CrossRef]

155. Pari, L.; Civitarese, V.; Assirelli, A.; Del Giudice, A. Il prototipo che abbatte i costi della raccolta del cardo. Inf. Agrar. 2009, 29, 8-11.

156. Natelson, R.H.; Wang, W.C.; Roberts, W.L.; Zering, K.D. Technoeconomic analysis of jet fuel production from hydrolysis, decarboxylation, and reforming of camelina oil. Biomass Bioenergy 2015, 75, 23-34. [CrossRef]

157. Larsson, M. Cultivation and processing of Linum usitatissimum and Camelina sativa in southern Scandinavia during the Roman Iron Age. Veg. Hist. Archaeobot. 2013, 22, 509-520. [CrossRef]

158. Berti, M.; Wilckens, R.; Fischer, S.; Solis, A.; Johnson, B. Seeding date influence on camelina seed yield, yield components, and oil content in Chile. Ind. Crop. Prod. 2011, 34, 1358-1365. [CrossRef]

159. Berti, M.; Gesch, R.; Eynck, C.; Anderson, J.; Cermak, S. Camelina uses, genetics, genomics, production, and management. Ind. Crop. Prod. 2016, 94, 690-710. [CrossRef]

160. Zubr, J. Qualitative variation of Camelina sativa seed from different locations. Ind. Crop. Prod. 2003, 17, 161-169. [CrossRef]

161. Vollmann, J.; Moritz, T.; Kargl, C.; Baumgartner, S.; Wagentristl, H. Agronomic evaluation of camelina genotypes selected for seed quality characteristics. Ind. Crop. Prod. 2007, 26, 270-277. [CrossRef]

162. Mupondwa, E.; Li, X.; Tabil, L.; Falk, K.; Gugel, R. Technoeconomic analysis of camelina oil extraction as feedstock for biojet fuel in the Canadian Prairies. Biomass Bioenergy 2016, 95, 221-234. [CrossRef]

163. Blackshaw, R.; Johnson, E.; Gan, Y.; May, W.; McAndrew, D.; Barthet, V.; McDonald, T.; Wispinski, D. Alternative oilseed crops for biodiesel feedstock on the Canadian prairies. Can. J. Plant Sci. 2011, 91, 889-896. [CrossRef]

164. Chen, C.; Bekkerman, A.; Afshar, R.K.; Neill, K. Intensification of dryland cropping systems for bio-feedstock production: Evaluation of agronomic and economic benefits of Camelina sativa. Ind. Crop. Prod. 2015, 71, 114-121. [CrossRef]

165. Gesch, R.W.; Archer, D.W. Double-cropping with winter camelina in the northern Corn Belt to produce fuel and food. Ind. Crop. Prod. 2013, 44, 718-725. [CrossRef]

166. Berti, M.; Samarappuli, D.; Johnson, B.L.; Gesch, R.W. Integrating winter camelina into maize and soybean cropping systems. Ind. Crop. Prod. 2017, 107, 595-601. [CrossRef] 
167. Royo-Esnal, A.; Valencia-Gredilla, F. Camelina as a rotation crop for weed control in organic farming in a semiarid mediterranean climate. Agriculture 2018, 8, 156. [CrossRef]

168. Peterson, A.T.; Berti, M.T.; Samarappuli, D. Intersowing cover crops into standing soybean in the US upper midwest. Agronomy 2019, 9, 264. [CrossRef]

169. Zanetti, F.; Christou, M.; Alexopoulou, E.; Berti, M.T.; Vecchi, A.; Borghesi, A.; Monti, A. Innovative double cropping systems including camelina [Camelina sativa (L.) Crantz] a valuable oilseed crop for bio-based applications. In Proceedings of the European Biomass Conference and Exhibition Proceedings, Lisbon, Portugal, 27-30 May 2019; pp. 127-130.

170. Dobre, P.; Jurcoane, S.; Matei, F.; Stelica, C.; Farcas, N.; Moraru, A.C. Camelina sativa as a double crop using the minimal tillage system. Rom. Biotech. Lett. 2014, 19, 9190-9195.

171. Florin, I.; Duda, M.M. Camelina sativa: A new source of vegetal oils Camelina sativa: A new source of vegetal oils Introduction Camelina, though cultivated for over 2000 years in the area for its seeds containing. Rom. Biotechnol. Lett. 2011, 16, 6263-6270.

172. Keske, C.M.H.; Hoag, D.L.; Brandess, A.; Johnson, J.J. Is it economically feasible for farmers to grow their own fuel? A study of Camelina sativa produced in the western United States as an on-farm biofuel. Biomass Bioenergy 2013, 54, 89-99. [CrossRef]

173. Yang, J.; Caldwell, C.; Corscadden, K.; He, Q.S.; Li, J. An evaluation of biodiesel production from Camelina sativa grown in Nova Scotia. Ind. Crop. Prod. 2016, 81, 162-168. [CrossRef]

174. Tepelus, A.; Rosca, P.; Dragomir, R. Biojet from hydroconversion of camelina oil mixed with straight run gas oil. Rev. Chim. 2019, 70, 3284-3291. [CrossRef]

175. Wang, Z.; Feser, J.S.; Lei, T.; Gupta, A.K. Performance and emissions of camelina oil derived jet fuel blends under distributed combustion condition. Fuel 2020, 271, 117685. [CrossRef]

176. Pietras, M.P.; Orczewska-Dudek, S. The effect of dietary camelina sativa oil on quality of broiler chicken meat. Ann. Anim. Sci. 2013, 13, 869-882. [CrossRef]

177. Orczewska-Dudek, S.; Pietras, M. The effect of dietary Camelina sativa oil or cake in the diets of broiler chickens on growth performance, fatty acid profile, and sensory quality of meat. Animals 2019, 9, 734. [CrossRef]

178. Halmemies-Beauchet-Filleau, A.; Shingfield, K.J.; Simpura, I.; Kokkonen, T.; Jaakkola, S.; Toivonen, V.; Vanhatalo, A. Effect of incremental amounts of camelina oil on milk fatty acid composition in lactating cows fed diets based on a mixture of grass and red clover silage and concentrates containing camelina expeller. J. Dairy Sci. 2017, 100, 305-324. [CrossRef]

179. Hixson, S.M.; Parrish, C.C.; Anderson, D.M. Use of camelina oil to replace fish oil in diets for farmed salmonids and atlantic cod. Aquaculture 2014, 431, 44-52. [CrossRef]

180. Toyes-Vargas, E.A.; Parrish, C.C.; Viana, M.T.; Carreón-Palau, L.; Magallón-Servín, P.; Magallón-Barajas, F.J. Replacement of fish oil with camelina (Camelina sativa) oil in diets for juvenile tilapia (var. GIFT Oreochromis niloticus) and its effect on growth, feed utilization and muscle lipid composition. Aquaculture 2020, 523, 735177. [CrossRef]

181. Pernak, J.; Łeggosz, B.; Klejdysz, T.; Marcinkowska, K.; Rogowski, J.; Kurasiak-Popowska, D.; Stuper-Szablewska, K. Ammonium bio-ionic liquids based on camelina oil as potential novel agrochemicals. RSC Adv. 2018, 8, 28676-28683. [CrossRef]

182. Pawlowska-Olszewska, M.; Puzio, I.; Harrison, A.P.; Borkowski, L.; Tymicki, G.; Grabos, D. Supplementation with camelina oil prevents negative changes in the artery in orchidectomized rats. J. Physiol. Pharmacol. 2018, 69, 109-116. [CrossRef]

183. Omonov, T.S.; Kharraz, E.; Curtis, J.M. Camelina (Camelina Sativa) oil polyols as an alternative to Castor oil. Ind. Crop. Prod. 2017, 107, 378-385. [CrossRef]

184. Li, X.; Mupondwa, E. Life cycle assessment of camelina oil derived biodiesel and jet fuel in the Canadian Prairies. Sci. Total Environ. 2014, 481, 17-26. [CrossRef]

185. Mohammad, B.T.; Al-Shannag, M.; Alnaief, M.; Singh, L.; Singsaas, E.; Alkasrawi, M. Production of multiple biofuels from Whole Camelina Material: A renewable energy crop. BioResources 2019, 13, 4870-4883. [CrossRef]

186. Krzyżaniak, M.; Stolarski, M.J.; Graban, Ł.; Lajszner, W.; Kuriata, T. Camelina and Crambe Oil Crops for Bioeconomy-Straw Utilisation for Energy. Energies 2020, 13, 1503. [CrossRef] 
187. Zanetti, F.; Gesch, R.W.; Walia, M.K.; Johnson, J.M.F.; Monti, A. Winter camelina root characteristics and yield performance under contrasting environmental conditions. Field Crop. Res 2020, 252, 107794. [CrossRef]

188. Li, X.; Mupondwa, E. Production and value-chain integration of Camelina Sativa as a dedicated bioenergy feedstock in the Canadian prairies. In Proceedings of the 24th European Biomass Conference and Exhibition, Amsterdam, The Netherlands, 6-9 June 2016; pp. 151-157.

189. Simsek, S. Effects of biodiesel obtained from Canola, sefflower oils and waste oils on the engine performance and exhaust emissions. Fuel 2020, 265, 117026. [CrossRef]

190. Oba, G.C.; Goneli, A.L.D.; Masetto, T.E.; Hartmann-Filho, C.P.; Michels, K.L.L.S.; Ávila, J.P.C. Artificial drying of safflower seeds at different air temperatures: Effect on the physiological potential of freshly harvested and stored seeds. J. Seed Sci. 2019, 41, 397-406. [CrossRef]

191. Martins, E.A.S.; Goneli, A.L.D.; Gonçalves, A.A.; Hartmann Filho, C.P.; Rech, J.; Oba, G.C. Physical properties of safflower grains. Part II: Volumetric shrinkage. Rev. Bras. Eng. Agric. Ambient. 2017, 21, 350-355. [CrossRef]

192. Pari, L.; Alfano, V.; Scarfone, A.; Toscano, G. Tecnologie Innovative per un Utilizzo Efficiente dei Co-Prodotti Agricoli; Compagnia delle Foreste: Arezzo, Italy, 2016.

193. Desai, B.B.; Kotecha, P.M.; Salunkhe, D.K. Seeds Handbook. Biology, Production, Processing, and Storage; Dekker, M., Ed.; Mareel Dekker: New York, NY, USA, 2004.

194. Tavares, G.R.; Massa, T.B.; Gonçalves, J.E.; da Silva, C.; dos Santos, W.D. Assessment of ultrasound-assisted extraction of crambe seed oil for biodiesel synthesis by in situ interesterification. Renew Energy 2017, 111, 659-665. [CrossRef]

195. Costa, E.; Almeida, M.F.; Alvim-Ferraz, C.; Dias, J.M. The cycle of biodiesel production from Crambe abyssinica in Portugal. Ind. Crop. Prod. 2019, 129, 51-58. [CrossRef]

196. Falasca, S.L.; Flores, N.; Lamas, M.C.; Carballo, S.M.; Anschau, A. Crambe abyssinica: An almost unknown crop with a promissory future to produce biodiesel in Argentina. Int. J. Hydrogen Energy 2010, 35, 5808-5812. [CrossRef]

197. Zhu, L.H.; Krens, F.; Smith, M.A.; Li, X.; Qi, W.; Van Loo, E.N.; Iven, T.; Feussner, I.; Nazarenus, T.J.; Huai, D.; et al. Dedicated Industrial Oilseed Crops as Metabolic Engineering Platforms for Sustainable Industrial Feedstock Production. Sci. Rep. 2016, 6, 1-11. [CrossRef]

198. Oliveira, R.L.D.; Dias, L.A.D.S.; Corrêa, T.R.; Ferreira, P.H.S.; Silva, M.F.D. Divergence and estimates of genetic parameters in Crambe abyssinica: An oilseed plant for industrial uses. Rev. Ceres 2018, 65, 500-506. [CrossRef]

199. Meijer, W.J.M.; Mathijssen, E.; Kreuzer, A.D. Low pod numbers and inefficient use of radiation are major constraints to high productivity in Crambe crops. Ind. Crop. Prod. 1999, 9, 221-233. [CrossRef]

200. Berti, M.T.; Johnson, B.L.; Manthey, L.K. Seed physiological maturity in Cuphea. Ind. Crop. Prod. 2007, 25, 190-201. [CrossRef]

201. Gettys, L.A.; Werner, D.J. Stratification unnecessary for germination of seeds of Stokes Aster [Stokesia laevis (J. Hill) Greene]. Proc Fla. State Hortic. Soc. 2001, 114, 250-251.

202. Goos, R.J.; Johnson, B.; Bourguignon, C. Preliminary evaluation of the soil application value of crambe meal. Commun. Soil Sci. Plant Anal. 2009, 40, 3211-3224. [CrossRef]

203. Zanetti, F.; Scordia, D.; Vamerali, T.; Copani, V.; Dal Cortivo, C.; Mosca, G. Crambe abyssinica a non-food crop with potential for the Mediterranean climate: Insights on productive performances and root growth. Ind. Crop. Prod. 2016, 90, 152-160. [CrossRef]

204. Adamsen, F.J.; Coffelt, T.A. Planting date effects on flowering, seed yield, and oil content of rape and crambe cultivars. Ind. Crop. Prod. 2005, 21, 293-307. [CrossRef]

205. Soratto, R.P.; de Souza-Schlick, G.D.; Fernandes, A.M.; Souza, E.D.F.C.D. Effect of fertilization at sowing on nutrition and yield of crambe in second season. Rev. Bras. Cienc. Solo 2013, 37, 658-666. [CrossRef]

206. Wu, W. Sustainable crop rotation for improving crop productivity and environmental safety: A book review. J. Clean. Prod. 2018, 176, 555-556. [CrossRef]

207. Zorzenoni, T.O.; de Andrade, A.P.; Higashibara, L.R.; Cajamarca, F.A.; Okumura, R.S.; Prete, C.C. Sowing date and fungicide application in the agronomic performance of oleaginous brassica for the biodiesel production. Rev. Ceres 2019, 66, 257-264. [CrossRef] 
208. Costa, E.; Almeida, M.F.; Alvim-Ferraz, C.; Dias, J.M. Cultivation of Crambe abyssinica non-food crop in Portugal for bioenergy purposes: Agronomic and environmental assessment. Ind. Crop. Prod. 2019, 139, 111501. [CrossRef]

209. Oplinger, E.S.; Oelke, E.A.; Kaminski, A.R.; Putnam, D.H.; Teynor, T.M.; Doll, J.D.; Kelling, K.A.; Durgan, B.R.; Noetzel, D.M. Crambe: Alternative Field Crops Manual; University of Wisconsin and University of Minnesota: Saint Paul, MN, USA, 1991.

210. Nelson, L.A.; Grombacher, A.; Baltensperger, D.D. Crambe Production. In Historical Materials from University of Nebraska-Lincoln Extension; University of Nebraska-Lincoln: Lincoln, NE, USA, 1993.

211. Santangelo, E.; Menesatti, P.; Pari, L.; Fedrizzi, M. Possibilità produttive e di meccanizzazione del crambe. Inf. Agrar. 1994, 50, 31.

212. Polito, L.; Bortolotti, M.; Battelli, M.G.; Calafato, G.; Bolognesi, A. Ricin: An ancient story for a timeless plant toxin. Toxins 2019, 11, 324. [CrossRef]

213. Khatiwora, E.; Adsul, V.B.; Kulkarni, M.M.; Deshpande, N.R.; Kashalkar, R.V. Spectroscopic determination of total phenol and flavonoid contents of ipomoea carnea. Int. J. ChemTech Res. 2010, 2, 1698-1701.

214. Scholz, V.; Silva, J. Prospects and risks of the use of castor oil as a fuel. Biomass Bioenergy 2008, 32, 95-100. [CrossRef]

215. Nautiyal, O.H. Castor Oil and Its Derivatives' With Market Growth, Commercial Perspective: Review. Org. Med. Chem. Int. J. 2018, 6, 1-13. [CrossRef]

216. Mohammed, T.H.; Lakhmiri, R.; Azmani, A.; Hassan, I.I. Bio-oil from Pyrolysis of Castor Shell. Int. J. Basic Appl. Sci. 2014, 14, 1-5.

217. Roxas Duncan, V.I. Of Beans and Beads: Ricin and Abrin in Bioterrorism and Biocrime. J. Bioterror. Biodef. 2011, 8. [CrossRef]

218. Reddy, K.R.; Matcha, S.K. Quantifying nitrogen effects on castor bean (Ricinus communis L.) development, growth, and photosynthesis. Ind. Crop. Prod. 2010, 31, 185-191. [CrossRef]

219. Wnuk, A.; Górny, A.G.; Bocianowski, J.; Kozak, M. Visualizing harvest index in crops. Commun. Biometry Crop Sci. 2013, 8, 48-59.

220. Alexopoulou, E.; Papatheohari, Y.; Zanetti, F.; Tsiotas, K.; Papamichael, I.; Christou, M.; Namatov, I.; Monti, A. Comparative studies on several castor (Ricinus communis L.) hybrids: Growth, yields, seed oil and biomass characterization. Ind. Crop. Prod. 2015, 75, 8-13. [CrossRef]

221. Baldanzi, P. 1998 Selection for Non-Branching in Castor Ricinus communis L. Plant Breed. 1998, 117, 392-394. [CrossRef]

222. Vandenborre, G.; Smagghe, G.; Van Damme, E.J.M. Plant lectins as defense proteins against phytophagous insects. Phytochemistry 2011, 72, 1538-1550. [CrossRef]

223. Evofuel and Fantini s.r.l Breakthrough in Mechanical Harvesting for Castor Bean. Available online: https://www.evogene.com/press_release/evofuel-fantini-s-r-1-announce-breakthrough-mechanicalharvesting-castor-bean/. (accessed on 25 February 2020).

224. Anjani, K. Castor genetic resources: A primary gene pool for exploitation. Ind. Crop. Prod. 2012, 35, 1-14. [CrossRef]

(C) 2020 by the authors. Licensee MDPI, Basel, Switzerland. This article is an open access article distributed under the terms and conditions of the Creative Commons Attribution (CC BY) license (http://creativecommons.org/licenses/by/4.0/). 